\title{
Tata-Porhanyó-bánya 2012-ben
}

\section{T. Dobosi Viola}

Kivonat

Abstract

Kulcsszavak

Keywords

Szerző • Author

Hivatkozás • Cite as

Kézirat történet • Article history

Jogok • Copyright
A Kőkor Kerekasztal eredeti célkitüzésének megfelelően, beszámolok azokról az eredményekról, amelyekre az 1995-2001 között végzett ásatások anyagának feldolgozása, valamint a korábbi ásatások és gyűjtések anyagának revíziója során jutottam 2012 végéig, s a kérdésekről és problémákról is, amelyek közben felmerültek.

\section{Tata-porhanyó-bánya in 2012}

In concord with the aims of the Lithic Research Roundtable, I report new results about the revision of $1995-2001$ and former excavations, as they stand in 2012. New problems and questions are also included in the study.

\section{középsô paleolitikum, kavicsipar}

Middle Palaeolithic, pebble industry

T. Dobosi Viola, Magyar Nemzeti Múzeum, 1088 Budapest, Múzeum krt. 14-16.

T. Dobosi, V. (2013) Tata-Porhanyó-bánya 2012-ben (Tata-porhanyó-bánya in 2012). Litikum 1:23-39. https://doi.org/10.23898/litikuma0002

Érkezés | Received: 2013. 10. 10. Elfogadás | Accepted: 2013. 10. 15. Közzététel | Published: 2013. 12.10.

(C) Az egyes szerző(k). Ez egy nyílt hozzáférésű publikáció, amit a Creative Commons 4.0 licensze véd. A termék szabadon használható, terjeszthető és sokszorosítható az eredeti szerző és forrás megjelölése mellett. | This is an open-access article distributed under the terms of the Creative Commons Attribution License, which permits unrestricted use, distribution, and reproduction in any medium, provided the original author and source are credited.

\section{A lelöhely topográfiája}

A Dunántúl északkeleti szöglete jól körülhatárolható geográfiai egység. Határa egy derékszögú háromszög, amelynek két befogója az Általér torkolattól Visegrádig nyugat-keleti irányban folyó, majd onnan észak-délire forduló Duna, átfogója pedig a Komárom-Százhalombatta vonal, amelynek felső szakasza egybeesik a Tatai árokkal. A kedvező adottságú, nagyjából 1200 négyzetkilométeres terület felszíne tagolt, faunája, flórája változatos, vízben és nyersanyagokban gazdag. Minden régészeti és történeti korban sűrün lakott. Az őskőkorban települési lehetőséget kínáltak a barlangok, folyóteraszok, mésztufa-medencék. Bár lelőhelysűrüségben újabban vetekedik vele a Cserhát, kulturális sokszínűsége figyelemre méltó. A középső paleolitikumot egy geológiai értelemben viszonylag szúk időtartamon belül a Jankovich-barlang, Érd, Tata, a Kiskevélyi barlang, Csákvár képviseli. A felső paleolitikum második feléből is számos lelőhelyet ismerünk a Duna-teraszokról és a barlangokból (epigravetti és ságvári fílumok) (Dobosi 1983:13-14).

\section{A helyszín}

Tatán a Kálvária-domb meghatározó geológiai képlet. Peremén egyik oldalon a Geológiai Park a rézkori kova-bánya gödreivel. A másik oldalán a mesterségesen felduzzasztott Öreg-tó nyugati partját mésztufa kibúvások szegélyezik.
Hosszú ideig bányászták manufakturális módszerekkel, felhasználásáról a római kortól vannak adataink. A 20. század elején, a gimnázium építésekor az Eszterházy-uradalom kőbányájának múvelését felhagyták. A bányagödör kommunális szemétlerakóvá züllött, majd a gimnázium kezdeményezésére rendezték a területet és sportpályát alakítottak ki (1. ábra). Előzékenyen meghagytak egy néhány méter széles sávot az eredeti bánya-udvarból, hogy a lelőhely hozzáférhető maradjon (2. ábra).

A tatai középső paleolit lelőhely felfedezésével a hazai őskőkorkutatás hajnalán egy olyan speciális települési formát, az átmenetileg kiszáradt mésztufamedencét ismertük meg, amelyből azóta is csak egyetlen újabb került elő. Több mint fél évszázaddal később, s csaknem látótávolságra: Vértesszőlős.

Az édesvízi mészkő keletkezését számos elmélet magyarázza különböző szempontok alapján: a lerakódás ideje, a felszín morfológiája, a víz hőmérséklete és ásványi összetétele stb. A lehetséges modellek közül csak azok jöhetnek számításba, amelyek az összes kedvező körülmény esetén lakható méretû medencét eredményeznek. Magyarországon több mint 500 mésztufa-előfordulás ismert. Vastagságuk a 20-30 métert, kiterjedésük pedig a néhány négyzetkilométert is elérheti. A hazai édesvízi mészkövek zöme termogén eredetû. A vízhőmérséklet $15-75^{\circ} \mathrm{C}$ közötti, a vízmélység $5 \mathrm{~cm}$-től 5 méterig, a lerakódás gyorsasága a napi 0,1 mm-tôl az évi 35 cm-ig terjed (Korpás 2003:135). 
Néhány szórványos, idősebb (kréta, késő miocén) elő-forduláson kívül negyedkori eredetűek. A paleomágneses mérések szerint két időszak a meghatározó:

- idősebb: a Matuyama chron C2n anomáliája körül;

- fiatalabb: (benne Vértesszőlős és Tata) a Jaramillo chronnal kezdődik és a Brunhes közepi fordított anomáliával zárul (Korpás 2003:142)

Scheuer Gy. és Schweitzer F. (1990) a hazai mésztufákat keletkezésük szerint 3 típusba sorolta. A Gerecsében a völgytalpi/ tavi-mocsári, és a kevert típusú a jellemző, amelyek a legöszszetettebb szerkezetet mutatják. A völgytalpi/tavi-mocsári

\begin{tabular}{|c|c|c|c|}
\hline $\begin{array}{l}\text { Gyứjtés éve } \\
\text { year of collection }\end{array}$ & $\begin{array}{l}\text { Ásató/gyứjtő } \\
\text { colector/excavator }\end{array}$ & $\begin{array}{l}\text { MNM leltári szám } \\
\text { HNM inventory number }\end{array}$ & $\begin{array}{l}\text { Darab } \\
\text { pieces }\end{array}$ \\
\hline 1909-1910 & Kormos Tivadar ásatása & $\mathrm{Pb} / 266-391$ & 126 \\
\hline 1958 & Vértes László ásatása & $\mathrm{Pb} 58 / 3-824$ & $9040^{*}$ \\
\hline 1959 & Vértes László ásatása & $\mathrm{Pb} 59 / 1, \mathrm{~Pb} 59 / 231-1654$ & $23171^{\star *}$ \\
\hline 1960-1970 & Skoflek István felszíni gyűjtése & $\mathrm{Pb} 82 / 387-453$ & 68 \\
\hline 1958-1959 & Vértes László (szilánkból kiemelve) & $\mathrm{Pb} 82 / 454-791$ & 351 \\
\hline 1958-1963 & Skoflek István felszíni gyűjitése & $\mathrm{Pb} 74 / 194-212, \mathrm{~Pb} 82 / 387$ & 19,296 \\
\hline 1994 & Homola István felszíni gyüjtése & $\mathrm{Pb} 96 / 133-158$ & 43 \\
\hline 1995 & Cseh Julianna és T. Dobosi Viola ásatása & $\mathrm{Pb}$ 96/159-475 & 927 \\
\hline 1996 & Cseh Julianna és T. Dobosi Viola ásatása & $\mathrm{Pb} 97 / 1-1490, \mathrm{~Pb} 98 / 1-375$ & 2256,2199 \\
\hline 1997 & Cseh Julianna és T. Dobosi Viola ásatása & $\mathrm{Pb}$ 99/392-785 & 3058 \\
\hline 1998 & Cseh Julianna és T. Dobosi Viola ásatása & $\mathrm{Pb} \mathrm{2000/1-423}$ & 3096 \\
\hline 1999 & Cseh Julianna és T. Dobosi Viola ásatása & $\mathrm{Pb} 2000 / 424-572$ & 967 \\
\hline 2000 & Cseh Julianna és T. Dobosi Viola ásatása & $\mathrm{Pb} 2001 / 42-225$ & 870 \\
\hline 2001 & Cseh Julianna és T. Dobosi Viola ásatása & $\mathrm{Pb} 2003 / 256-335$ & 399 \\
\hline 2004 & Markó András felszíni gyűjtése & $\mathrm{Pb} 2004.39 .1-40.1$. & 2 \\
\hline 2009 & Cseh Julianna, tisztítás & $\mathrm{Pb} 2009.04 .1-17$ & 46 \\
\hline folyamatos // continuous & vegyes // mixed ${ }^{\star \star *}$ & $\mathrm{~Pb} 2013.1 .1-62$ & 308 \\
\hline összesen // total & & & 47242 \\
\hline
\end{tabular}

1. táblázat. Tata kutatásának állomásai.

A leltározás során Vértes $L$. az egy tételszámon beleltározott szilánk és töredék mennyiségét súlyra adta meg.

* A revízió és a nyersanyagok elkülönítése során az 1958. és 1959. évi leltározásánál feltüntetett szám az eszközök és az 5 mm-nél nagyobb szilánkok darabszáma. A szilánkokból kiválogatott, 5 mm-nél kisebb gyártási hulladék a szilánkokkal azonos leltári számon, súlyra és nem darabszámra van nyilvántartva.

** Az 1959. évi leltározásban benne van a bánya két külső pontján, a lelőhelytől függetlenül talált két szilánk, valamint a lelőhelyről előkerült 17 db megmunkált csont és csonttöredék, okker stb.

*** A szilánkanyagból utólag kiemelt és a lelőhely alkalmi meglátogatása, takarítása során előkerült tárgyak.

Table 1. Tata research history.

L. Vértes counted the quantity of flake debitage and chips as weight under one item number, instead the number of pieces.

* Concerning the 1958 and 1959 inventory, the given number denote the tools and flakes bigger than 5 millimeters only. The smaller pieces are recorded the same inventory number as the bigger flakes, but their sum weight is given instead of the number of pieces.

** The 1959 inventory contains two flakes found outside the archaeological site, and 17 pieces of worked bones, bone fragments, ochre lumps etc

*** Artefacts that are separated earlier from the excavated material, and other pieces found during excursions and site maintenance.

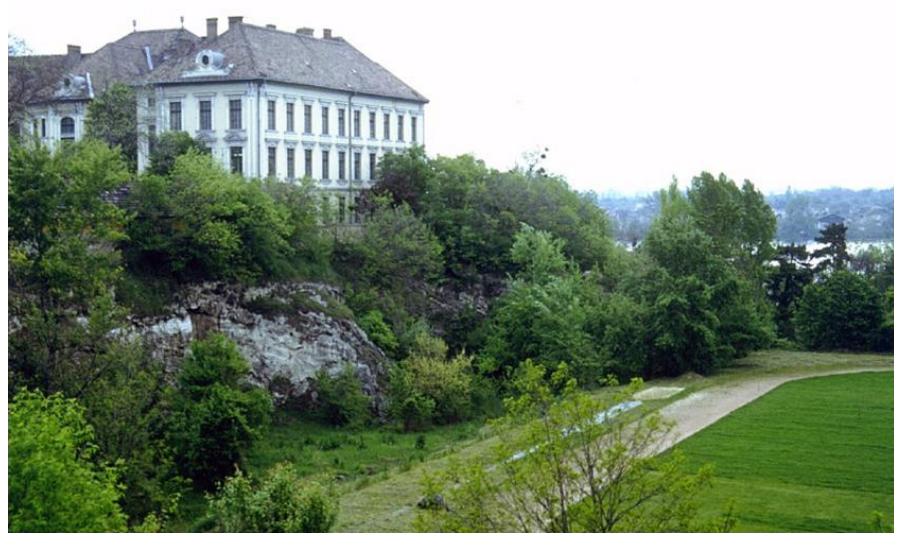

1. ábra. A lelőhely a gimnázium épületével, és az Öreg-tóval. // Figure 1. The site with the school buiding and the Öreg-tó (Old Lake).

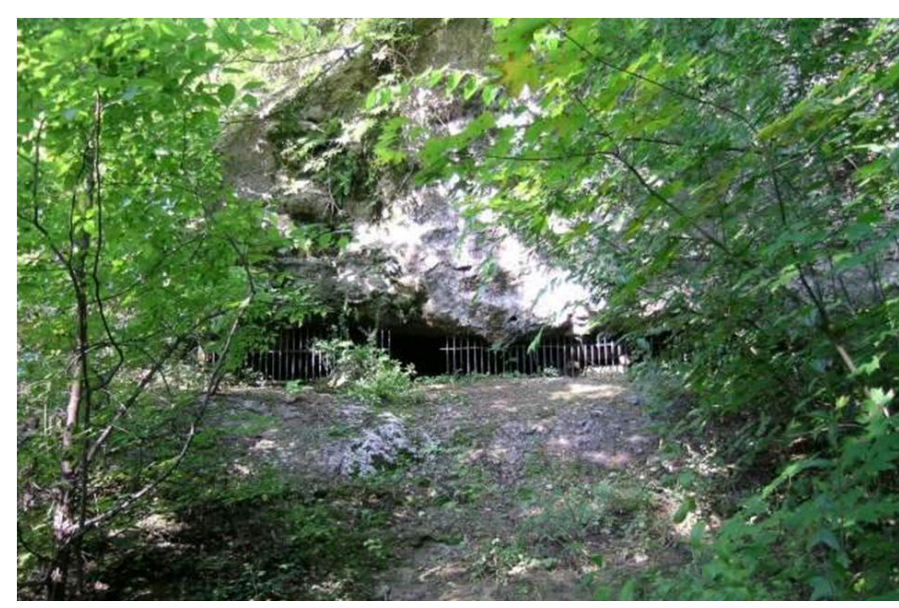

2. ábra. A lelőhely „bejárata”. // Figure 2. "Entrance" of the site. 


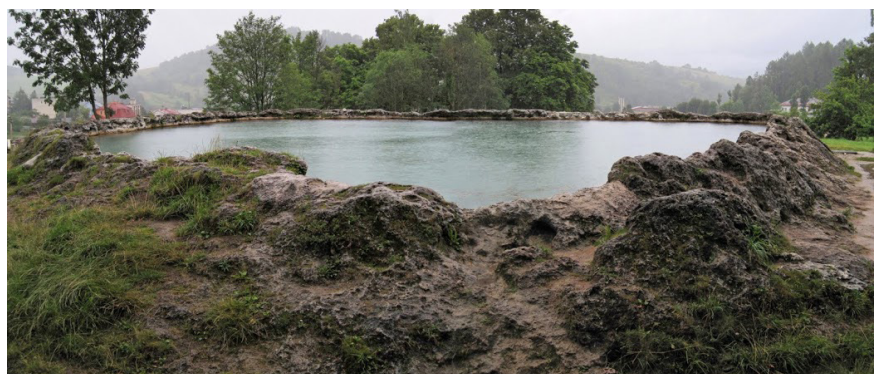

3. ábra. Vyšné Ružbachy (Felsőzúgó), mésztufamedence. Fotó: Jiří Horá. Forrás:

https://picasaweb.google.com/lh/photo/EX9uhd0fvi_DT7gsTrbrYw //

Figure 3. Vyšné Ružbachy (Felsőzúgó) travertine basin. Photo: Jiří Horá. Source:

https://picasaweb.google.com/lh/photo/EX9uhdOfvi_DT7gsTrbrYw

mésztufaképződésre a vízszintes vagy közel vízszintes rétegződés a jellemző. Vértesszőlősön ezt a típust azonosították (Scheuer, Schweitzer 1990: 49-51, Pl. III.1.). A Tata-monográfiában Vértes L. teraszlejtőn képződő medencét rekonstruált (Vértes 1964: Abb. 5). Az újabb kutatások, az üledék- és karbonáttartalom vizsgálatokkal megerôsített morfológia is a tavi modellt erósítik (Kele et al. 2006) (3. ábra).

\section{Tipológia}

Elsődleges adataink szerint Tatán a leletanyag 6,5\%-a standard eszköz. A tatai leletanyagról 2004-ben jelent meg részfeldolgozás (Dobosi 2004). Ez 1-2\% eltérést mutat, de az alapképlet ugyanaz. Az 1964-es monográfia intenzitás-térképéhez, a négyzetméterenkénti leletsűrűség illusztrálásához (Vértes 1964: Abb. 3.) nem tudunk közvetlenül csatlakozni, hiszen a legtöbb leletanyagot a leomlott, bolygatott törmelékben gyưjtöttük. In situ települési felszín csak néhány négyzetdeciméter volt, a medence előterében. A mi tapasztalatunk is az, hogy a település a medence északi részén volt intenzívebb.

A tipológia jelentőségének, súlyának megítélése folyamatosan változik. Most a kevésbé ortodox szemlélet erősödik, a forma és a stílus mellett új szempontok kapnak hangsúlyt (4. ábra).

N. Rolland és H. L. Dibble 1990-ben megjelent fontos tanulmányában a paleolit iparok változatosságát vizsgálja annak előrebocsátásával, hogy a hosszú ideig tartó, erőteljes posztdepoziciós események jelentősen megnehezítik az eredeti viselkedési mintázatok rekonstruálását. Az eszközkészletek variabilitását számos egyéb összetevő mellett a stílus és funkció határozza meg, bár az ember a készterméket sohasem különbözteti meg tisztán stilisztikai vagy funkcionális különbségek alapján. A stílust és technikát a nyersanyag minősége, hozzáférhetôsége, mérete: a nyersanyagból hasznosan felhasználható anyag mennyisége határozza meg. Egyes iparok nyersanyag hasznosítása, az adott nyersanyag gazdaságos felhasználása (reduction intensity) között esetenként jelentős különbség mutatkozik, esetenként nincs különbség. Az okát még nem ismerjük. Egy típuscsoporton belül a formális ismérvek alapján elkülönített típusok (pl. F. Bordes kaparói) nem különálló kategóriák, hanem a folyamatos megújítás, alakítás eredményei. (Roland-Dibble 1990:482-485). Ennek magyarázata az ún. Frison-effektus. G. Frison paleoindián mamutvadászokkal foglalkozó amerikai régész általános érvényű megfigyelése, amit A. Jelínek (1976) fogalmazott meg: a kőeszközök folyamatos újraélezése az eszköz formáját és a használat módját is megváltoztatja, a végeredmény nem is hasonlít az eredeti (tervezett) tárgyra.

Minden korszak vagy lelőhely típuslistájának összeállításánál ajánlatos figyelembe venni. Például bizonyosan nem volt 50 különbözô funkciója a vértesszőlősi alsó paleolitikus eszközkészlet Vértes által elkülönített 50 típusának, s kérdéses a felső paleolitikus 90 önálló típus létjogosultsága is. (Bár a környezeti feltételek igen lényegesen különböznek a jégkoriaktól, mégis említésre méltó, hogy egyes, hosszú ideje eredményesen túlélő trópusi közösségek teljes eszközés fegyvertára alig haladja meg a kihegyezett bot szintjét). Egy-egy egyedi, speciális technikai megoldás gyakorisága

2. táblázat. Eszköztípusok Tatán. * leltárkönyvi állapot; ** a 2013. évi leltározás nélkül; *** a kaparók és a valószínűleg azonos funkciójú kaparókések dominanciája meghatározó (71\%) //

Table 2. Lithic tool types of Tata. * inventory list state; ** without the 2013 inventory; ${ }^{* * *}$ dominant types (71\%) are side-scrapers and sidescraper knives, supposedly with similar functions.

\begin{tabular}{lrl}
\hline Alsó paleolitikus típusok (lower palaeolithic types) & & \\
\hline Szakóca / Handaxe & 12 & 0,42 \\
Chopper+kombinációi / Choppers & 88 & 3,08 \\
Chopping-tool+kombinációi / Chopping tools & 65 & 2,28 \\
Egyéb kavicseszköz / Other pebble tools & 8 & 0,28 \\
Rostrocarinata / Rostro-carinates & 11 & 0,38 \\
Összesen / Tools & 184 & 6,44
\end{tabular}

Középső paleolitikus típusok (middle palaeolithic types)

Hegyek (moustérien, Tayac-(?), levél-) /

Points (Mousterian, Tayac, Leaf-shaped)

8

0,28

Kaparók+kombinációi /

Side-scrapers \& combinations

1882

65,87

Kaparókés*** / Scraper-knives***

Fogazott, völgyelt / Notches \& denticulates

1,40

Bifaciális megmunkálás / Bifacial pieces

1,65

Összetett / Combined tools

Összesen / Tools

2180

76,30

Felső paleolitikus típusok (upper palaeolithic types)

Vakaró+gyaluvakaró / End-csrapers \& Rabots

Árvésők+kombinácói /

Dihedral burins \& combinations

Fúró / Borers

Véső / Burins

Megmunkált, csonkított, tompított /

Backed, truncated \& other worked tools

Pengehegy, vállas, nyeles /

Points, pedunculated \& shouldered points

Geometrikus mikrolit, trapéz, ék /

Geometrics, trapezes, wedges

Összesen / Total

Összes vizsgált eszköz** / All tools** 


$\begin{array}{lr}\text { Típus / Type } & \text { db / pcs } \\ \text { Gerezd / Segment } & 616 \\ \text { Szelet / Slice } & 72 \\ \text { Gúla / Pyramid } & 29 \\ \text { Plagiolit / Plagiolith } & 8 \\ \text { Negyed kavics / Quarter pebble } & 85 \\ \text { Geometrikus töredék / Geometric fragment } & 141 \\ \text { Retusált szilánk / Retouched flake } & 299 \\ \text { Retusált töredék / Retouched fragment } & 98 \\ \text { Penge, pengeszerű szilánk / Blade, bladelike flake } & 232 \\ \text { Magkő + -maradék, -töredék, -talp, -perem / } & 182 \\ \text { Core, -remnant, -fragment, -platform, -edge fragment } & \\ \text { Retusőr (triász mészkő) / Retoucher (limestone) } & 55 \\ \text { Ütőkő (kova, kvarcit) / Hammerstone (flint, quartzite) } & 5 \\ \text { Üllő (néhány hosszúcsont-töredék) / } & + \\ \text { Anvil (long bone fragments) } & \mathbf{1 8 2 2} \\ \text { Összesen / Total } & \end{array}$

3. táblázat. Nem-standard eszközök. // Table 3. non-standard tools.

azonban legalább fácies értékú különállást biztosíthat egyegy leletegyüttesnek még akkor is, ha nem új funkcióhoz alakítanak ki új eszközt.

Vértes egyes típusokhoz magyarázatot füzött. A feltehetően azonos vagy közeli funkciójú típusokat megmunkálás alapján különböztette meg.

A kaparó kategórián belül szignifikánsan elkülönült egy eszközcsoport, amelyet felszíni és lépcsős retussal állítottak elő. Ezek a kaparókések. A klasszikus kaparók lépcsős retussal készültek (Vértes 1965: 260) (5. ábra).

A chopper és chopping-tool csoportra, valamint a lelőhelyrôl elnevezett Tata-kaparóra az archaikus szakóca-retus jellemző (Vértes 1964: 190).

Ez a Tatán elkülönített típus sem elég karakteres, sem olyan nagy számban nincs jelen az anyagban, hogy egy külön a lelöhelyről elnevezett kategória bevezetése jogosult lenne. Vértes maga írja: „...in gewissen Fällen kann man die zwei Gruppen auf Grund der Eigenheiten nicht voneinander absondern" (Vértes 1964:155). Ezeket az eszközöket a megmunkálás módja (szakóca-retus), formája alapján a chopping-toolokhoz, vagy a bifaciális, illetve a munkaél alakjának megfelelő kaparókhoz soroltuk.

A rostrocarinata (rostro: csőr vagy hajóorr, carinate: csónak) már az alsó paleolitikumban megjelenő, egyik legfejlettebb típus, a többi kavicseszközhöz hasonlóan nagy túlélő. Széles talpú, magas, többnyire természetes (kavicskérges) hátú gerezd, egyik vége hegyes, másik vége retusálással lekerekített, de többnyire itt is megmaradt a kavics gömbölyded kérge, retusált, hegyes vége ellaposodik. Jellemző rá a meredeken felfutó, a gerezd nagy területére kiterjedő lépcsős megmunkálás. A típust Vértesszőlősön különítette el Vértes László. Az 1964-es monográfiában Tatáról nem említi.
Statisztikai számítások alapján két nagy eszközcsoportnál talált kapcsolatot a típus és a hosszúság-szélesség arány között: a középső paleolitikus vezértípusok, a kaparók kifejezetten zömökek (plump), míg a felső paleolitikus árvésők - mint az várható - karcsúak (schlank) (Vértes 1964:197).

Vértes a vértesszőlősi feldolgozás kapcsán különítette el a nem-standard eszközök csoportját. Azok a tárgyak tartoznak ide, amelyek nem sorolhatók be a klasszikus régészeti tipológiába, ám alapvetően meghatározzák egy-egy leletanyag karakterét: hiteles, bolygatatlan régészeti kontextusban, nagy darabszámú sorozatokban előkerült, azonos technikával különböző alakúra felhasított kavicsok, további megmunkálás nélkül (Vértes, 1990:302).

Olyan szabályos, többnyire geometrikus formák, amelyek egyrészt lehetnek ad hoc eszközök, mert a természetes hasadási él is alkalmas a munkavégzésre (5. ábra). Másrészt olyan eszköz-alapformák, amelyeket további retusálással a hagyományos tipológia valamelyik típusává alakítanak. A tojásdad kavicsokat felezik: ortolit (hosszában), hemilit (keresztben), plagiolit (ferdén), ezeket tovább aprítják negyed alakúra vagy negyednél nagyobbra. Gyakori a gúla, Tatán a lapos gúla alakú szilánk. A kaparók jelentős részének alapformája a (citrus)gerezd, (segment, Zitrus-schaber, a spicchio, Fruchtscheiben-schaber stb.), amely háromszög keresztmetszetû, hátoldalán kavicskéreggel, és gyakori a (kör)szelet (slice) alakú kavicsszármazék, amely négyszög keresztmetszetű, körben kavicskéreggel.

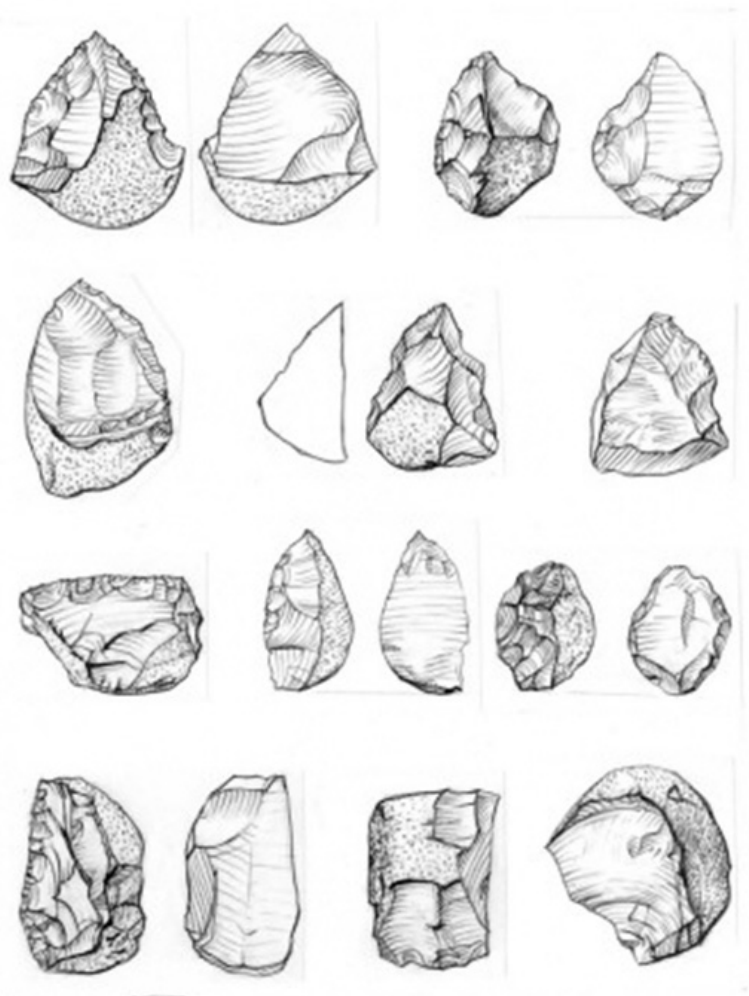

4. ábra. Tatai eszközök. Rajz: Nagy K. // Figure 4. Tata tools. Drawing: K. Nagy 

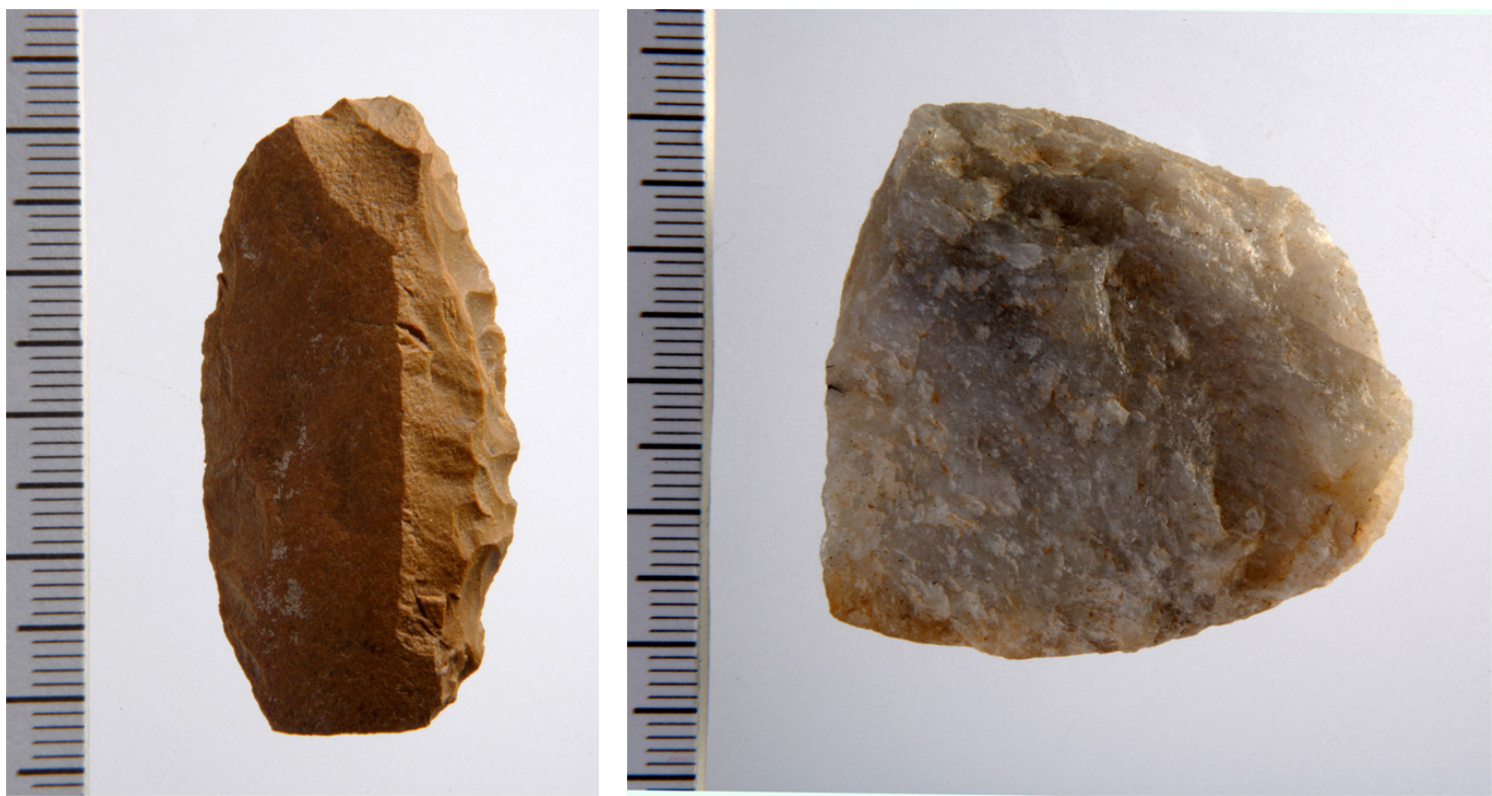

5. ábra. Tata eszközök. Balra - szegletes kaparó; jobbra - kvarcit gerezd. Fotók: Dabasi A. // Figure 5. Tata, tools. Left - square side-scraper; right - quartzite segment. Photos: A. Dabasi

\section{Technológia}

A típusok konvencionális megnevezése a feltételezett használati módból következik, bár az eszközök morfológiája más lehetőséget sem zár ki. A hegyek pl kézben tartva daraboló kés, fa nyélbe erősítve dárdahegy (Valoch 1988). A funkciótól elválaszthatatlan a méret. A taubachi kör, ezen belül Tata eszközkészletének legnagyobb - eddig fel nem oldott - ellentmondása éppen a méret önmagában is, és különösen, ha összevetjük a zsákmányállatok méretével. Anatómiájukból következően a neandervölgyiek jobb fizikai adottságokkal rendelkeztek, mint a sapiensnek. Ám bármekkora fizikai erőt tulajdonítunk is nekik, s az eszközeik kivitelezéséből nyilvánvaló a magas szintû manuális képességük, a $30 \mathrm{~mm}$ átlagméretü, közvetlenül a kézben tartott szerszámokkal elég körülményes lehetett megbirkózni a zsákmányolt vastagbőrüekkel. A tényleges használat módját a kopásnyom vizsgálatokkal rekonstruálhatnánk. A Tatán előkerült összes tárgyra kiterjedő traszológiai vizsgálat lehetne a probléma megoldásához vezető egyik út. Ez a feladat egy kutató teljes szakmai pályafutásába is alig fér bele, még ha akadna is valaki, aki belevág, s lenne intézmény, amely finanszírozza.

Vértes László némi előzmény, bevezető ujjgyakorlat után a tatai ásatás anyagának feldolgozása során alkalmazta teljes gazdagságban az őskőkori leletekre adaptált matematikai statisztikai módszerét (Vértes 1964:142-244).

Lyukszegély kártyás nyilvántartás (6. ábra) után minden létező metrikus adattal számításokat végzett. A feldolgozásban kivédhetetlen szubjektivitást kívánta elkerülni azzal, hogy a regisztráló statisztika (F. Bordes indexei) helyett az eloszlási törvényszerúségekkel határozott meg egy ipart és annak kapcsolatrendszerét (Vértes 1965:256). A módszer redukált formában utoljára a Vértesszőlős-monográfiában (KretzoiDobosi 1990) tûnt fel a még az ásató életében befejezett lyukszegélykártyás nyilvántartás felhasználásával. További követőkről nincs tudomásom.

Ebből a kissé már öncélú, aprólékos adathalmazból legalább az átlaghosszúság és a hosszúság-szélesség arány átlagát célszerủ megtartani, egyrészt mert a méret és a laminarizáció mértéke meghatározó jellemvonásai egy eszközkészletnek, másrészt mert ezáltal kiküszöbölhető az eszközrajzok és fotók okozta bizonytalanság.

Vértes L. eredményei (1964-es állapot) (Vértes 1965:371-372):

- Hosszúság: 1995 db adatai alapján az átlagméret 30,25 mm és a szórásnégyzet 104,99.

- Hosszúság-szélesség arány: 2153 db adatai alapján 65,26\% és a szórásnégyzet 78,90.

- Leütési szög: 541 db átlaga alapján 111,28 és a szórásnégyzet 66,65.

- Megmunkált leütés: $137 \mathrm{db}=$ 24\%.

- Bifacialitás: $40,2 \%$.

Összességében a tatai iparra a rendkívül szúk szórás alapján az erősen specializált középső paleolitikus eszközelőállítási technika (,...stark spezialisierte mittelpaläolithischen Werkzeugherstellungstechnik") a jellemző (Vértes 1964:199).

A tömött, homogén szövetű, igény szerint könnyen alakítható radiolarit preferálása is hozzájárult a tatai iparra jellemző standard technológiai szint eléréséhez. A szükséges manuális készségek birtokában, a mindennapi igények kielégítéséhez szükséges kis méretű eszközök előállításához válogatták ki a megfelelő méretû kavicsokat. Vértes László technológiai kísérleteinek eredményeképpen bebizonyosodott, hogy a kavics gömbölyded felszínére mért ütés hasonló leütési felszínt eredményez, mintha Levallois-magkőről választották volna le a szilánkot. Úgy vélte, hogy ennek a technikai sajátosságnak a felismerése vezetett a speciális kavics nyersanyag kiválasztásához (Vértes 1965:108). ez egy újabb kísérlet a kavics nyersanyag túlsúlyának magyarázatára. 


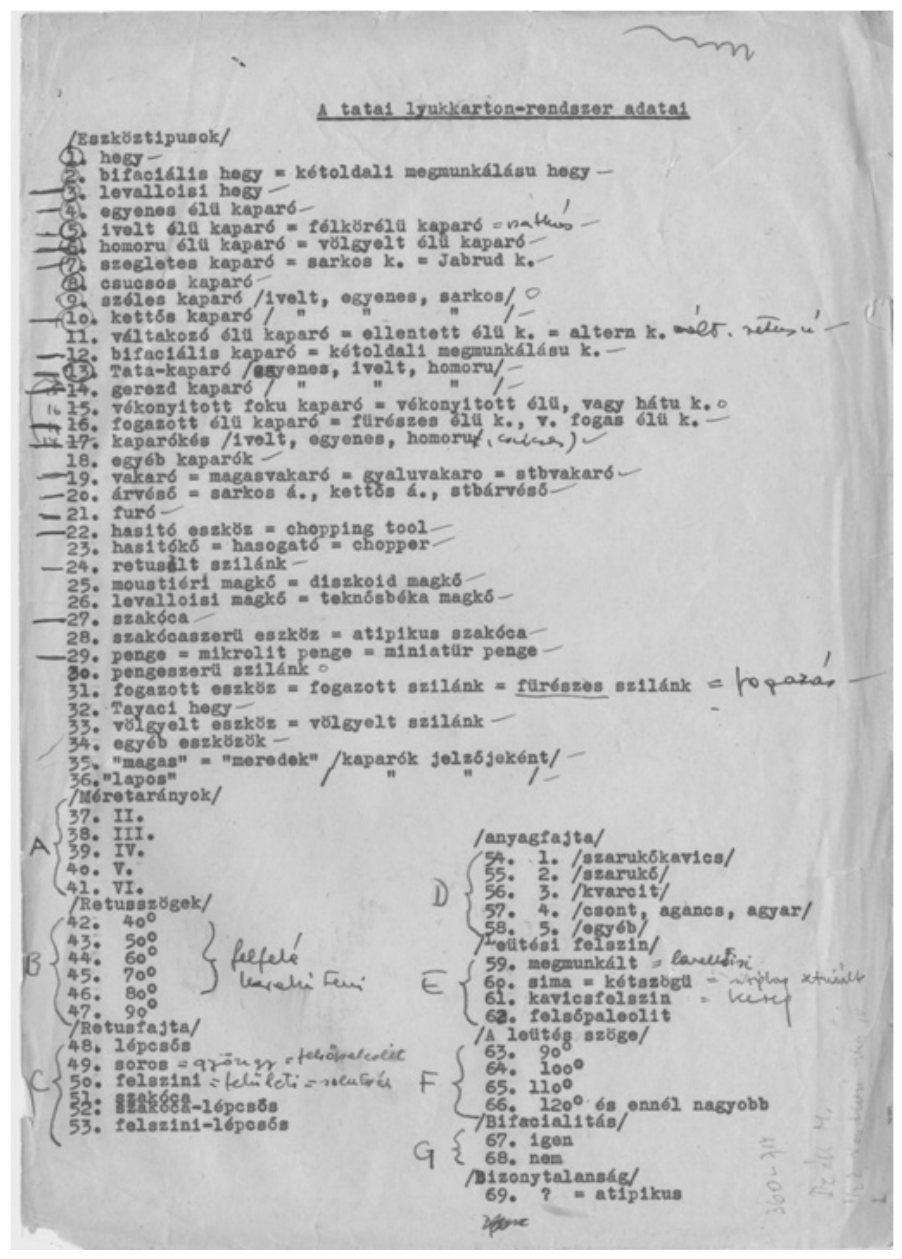

6. ábra. Kódok a lyukszegély kártyához. Vértes L. kézirata. // Figure 6. Code sheet for the punchcards used by L. Vértes. Manuscript of L. Vértes.

A tatai ipar kapcsolata a jelentősebb középső paleolitikus eszközegyüttesekkel a statisztikai adatok alapján (Vértes 1964:236):

- Subalyuk, a későmoustéri fáciese a legközelebbi;

- a Szeleta barlang anyagával lazább, (de van!);

- a Jankovich barlanggal pedig jelentéktelen a kapcsolat.

A valószínűség számítás és a statisztikai tesztek szélsőséges alkalmazásakor, egy-egy metrikus jellemzőnek az egészből való kiragadásával olyan eredmények is születhetnek, amelyek ellentmondanak minden egyéb adatnak és következtetésnek.

A megmunkálás változatos, leggyakoribb a lépcsős re-tus (20\% körül), van soros és felszíni retus is. Magas a kétoldali megmunkálás aránya (közelíti a 40\%-ot), ami levezethető a genetikus előzményekből, az alsó paleolit kavicsiparok hagyományaiból. Ugyanez a véleménye K. Valochnak, miszerint a tatai eszközanyagban mutatkozó jelentős bifacialitás nem funkcionális igény, hanem a hagyományok követésének eredménye (Valoch 1988:92). Ami végül is nem ellentmondás: azt a technikát, ami a középső paleolitikumban már hagyomány, valamilyen (funkcionális) igény kielégítésére fejlesztették ki az elődök. A többnyire csak az él megmunkálására korlátozódó kétoldali megmunkálás amúgy sokkal finomabb és élesebb munkaélet eredményez, amit gyakorlatban tapasztalhattak, s ami a hatékonyság szempontjából sem közömbös.
Az eszközök készülhetnek redukciós módszerrel és szupport-szilánkokon is. A technológia meghatározó elemei között előfordulnak:

- archaikus elem pl. a geometrikus töredékek magas aránya és a chopper-retus gyakorisága (nehézségek vannak a chopperek és a durva retusú kaparók elkülönítésében!);

- a felső paleolitikumban gyakori a Tatán is megjelenő csonkítás, vagy az azt helyettesítő ferde leütés, valamint a szilánkok többnyire disztális végének vakaró- vagy fúrószerü megmunkálása;

- a kőeszköz-megmunkáló technika a kulturális szintnek megfelelő, gyakori a fogazás/völgyelés.

Az eszközök szokatlanul kis méretéből az elkészítésben és a használatban egyaránt adódó gyakorlati nehézségeknek (precíz fogás, kellő erőkifejtés) az eredményes megoldása jól illusztrálja a középső paleolitikus ember szellemi és manuális képességeit. Ez a megállapítás a hasonló méretű eszközkészlet ismeretében fokozottan érvényes a legalább egy evolúciós lépcsővel idősebb vértesszőlősi emberre is.

Kézügyességük másik bizonyítéka a mamutfog lemez. A gondosan formált, peremén egyenletesen csiszolt, részben profilált, felületén polírozott és nyomokban okkerrel színezett tárgyat több publikációban csak kérdőjellel sorolták a régészeti leletek közé. Néhány kutató - látatlanban - nem találta meggyőzőnek az emberi kéz munkáját a tárgyon (EiblEibesfeldt 1995:28): „...mamut-agyarból készített, okkerrel színezett lapocska, eredetéról megoszlanak vélemények. Lehetséges, hogy a természet formálta ilyenné, de az is elöfordulhat, hogy ember készítette" (7. ábra). A kételkedés helyett meg kell nézni a tárgyat eredetiben, és összehasonlítani egy megmunkálatlan, az őrlőfogról természetes úton lehasadt vagy leválasztott lemezzel. A tárgy fotója elég indokolatlanul "Az elsó emberek, az ember képes története" című album Agresszió és háború című fejezetének illusztrációja (Eibl-Eibesfeldt 1995:28). Kivitelezésének tudatossága és minósége egyértelmú. A tárgy kissé erőltetettnek tûnő néprajzi analógiákkal alátámasztott spirituális jelentőségé-re itt nem térünk ki (Vértes 1964:190). Az azonban bizonyos, hogy többszörösen megfelel a N. Rolland által megfogalmazott feltételeknek, amikben a középső paleolitikus ember szimbolikus viselkedésének bizonyítékát látja: ,the use of colourants, the collection or shaping of non-utilitarian objects" (Rolland 1990:376).

Az utóbbi években a tatai ipar technológiájával foglalkozó irodalom fontos dolgozatokkal bővült M.-H. Moncel jóvoltából. A taubachi eszközkészítő technikát elemző tanulmányai közül többet is szentelt Tatának (Moncel 2001; 2003a; 2003b; 2003c; 2004).

Az emberek a különböző minőségű nyersanyaghoz adaptálták a technológiát, aminek sok közös vonása van Kůlna, Tata és Taubach lelőhelyeken. Az összefoglalóan diszkoid családnak (discoidal family) nevezett lelőhelycsoportra a két ellentétes szilánkolási felszínnel rendelkező magkövek (cores with two opposite flaking surface) használata a jellemző, ami eléri a 70\%-ot.

A másik nagyobb csoport a négyszögletes kavicsokon alkalmazott leválasztás, amely ortogonális szilánkolási felszínû magköveket (cores with orthogonal flaking surface) eredményez. 
A szilánkok többnyire vastagok, szélesek, alakjukat a nyersanyag finomsága és az alkalmazott technika határozza meg (Moncel 2004:105).

\section{Nyersanyag}

Általános érvényű tapasztalat, hogy az alsó paleolitikumtól a felső paleolitikum felé haladva bővül egy-egy közösség mozgáskörzete, aminek tárgyi bizonyítéka a felhasznált nyersanyag beszerzésének egyre táguló köre. A korai hominidák telephelyének kiválasztásánál egyrészt döntő szempont lehetett a kedvelt nyersanyaguk közelsége, másrészt a nyersanyagok minőségével szemben támasztott igény is egyre nő az idő előre haladtával. Ez kimutatható, ha van mód egy lelőhely több települési szintjének összehasonlítására is (pl. Vértesszőlős - Dobosi 2003: tab. 4.).

A tatai nyersanyagokra is érvényes a három alapvető probléma: a kőzettanilag pontos meghatározás nehézségei, a kavics beszerzésének lehetséges forrásai, a felhasználás mértéke a teljes leletanyagon és egy-egy típuson belül.

\subsection{Kőzettani kérdések}

- Amit Kormos Tivadar következetesen jáspisnak nevezett, az ma radiolarit. Van mustársárga, májbarna, szentgáli vörös (világos sárga szegéllyel) változat. Ha primer forrásból gyưjtötték, akkor általános érvényü-e az a tapasztalat, hogy a színváltozatok egyben a nyersanyagok topográfiai elkülönítését is jelent(het)ik.

- A Vértes-féle jáspist tételesen el kell különíteni a kalcedontól, ha az egyáltalán kalcedon.

- Meg kell határozni egy hamuszürke-sárgásszürke finomszemcsés nyersanyagot, hogy az kova, kvarcit-féleség vagy szarukő.

- A szarukő és a szürke kova csak geológiai kontextusban különíthető el megbízhatóan (amire T. Biró K. hívta fel a figyelmemet) vagy szubjektíven is (színre, fényre, tapintásra) megkísérelhető a szétválasztás.

- Lidit-e, ami fekete?

- Hidrotermális-e, ami annak látszik (még opál-szerú darabot is találtunk)?

- Eddig fel nem ismert, „új” nyersanyagok azonosítása és beszerezhetőségének vizsgálata (Markó András új kutatásai - Markó-Kázmér 2004).

- roncsolásmentes anyagösszetétel-vizsgálat (Kasztovszky et al. 2009) (és ebből következően a származási hely azonosítása), kiegészítve vékonycsiszolat-elemzéssel.

\subsection{A nyersanyagforrások}

Vértes $40 \%$ körülire becsülte a tömbnyersanyagot (Silex). Beszerzési helyeként a Kálvária-hegy jura kori tưzköves rétegeit valószínúsítette. A néhány száz méterre lévő dombtetőn rézkori bányagödrök kerültek elő. Ezeket olyan, a felszínre kiékelődő kibúvásokat követve nyithatták, amelyek a paleolitikumban is hozzáférhetők lehettek. Távolabb, a Gerecse számos pontján borítja a felszínt a felaprózódott pados radiolarit (pl. Pisznice-tető). Az időjárásnak hosszan kitett, felszíni kovatörmelék minősége folyamatosan romlik, kevéssé alkalmas a finom megmunkálásra. Az elhanyagolható

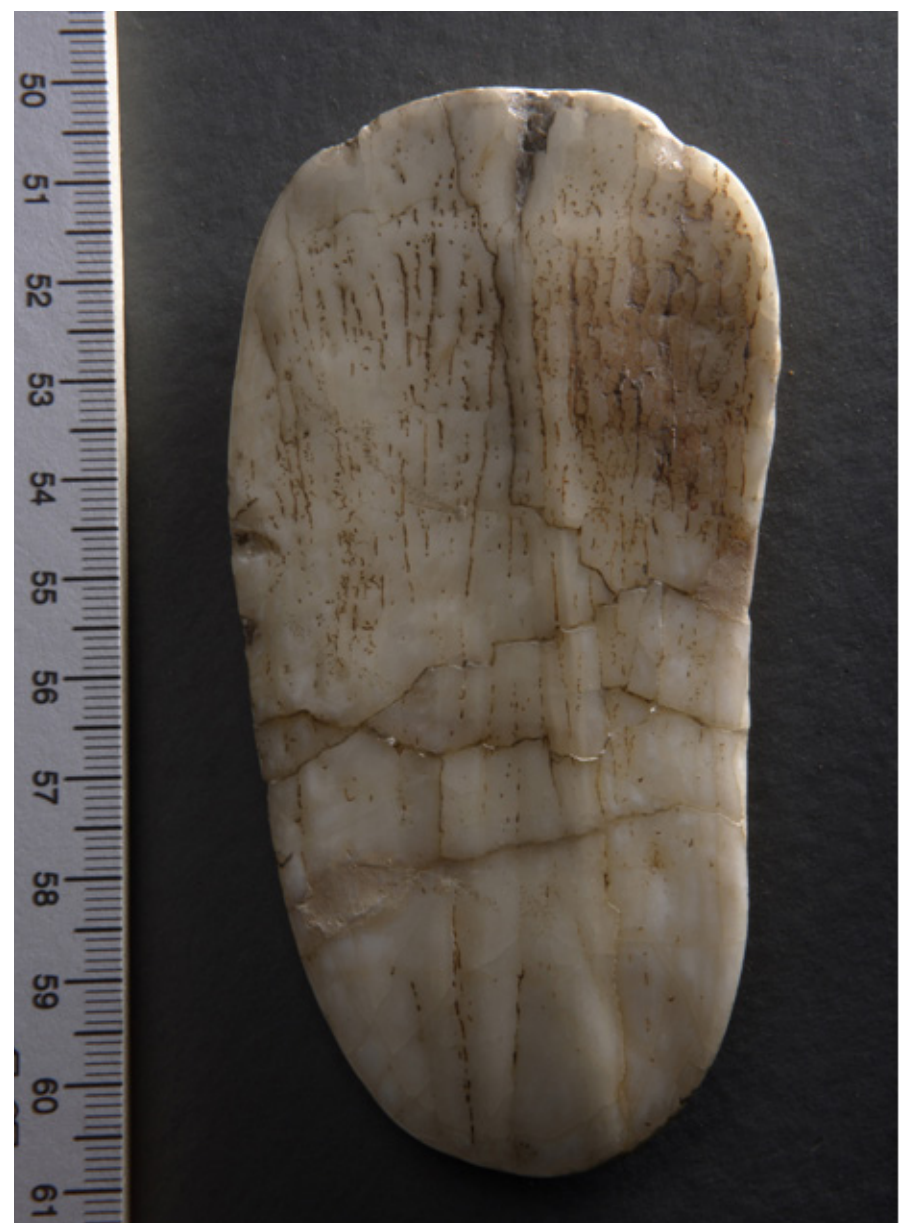

7. ábra. Csiszolt mamutfoglemez. Fotó: Dabasi A. //

Figure 7. Polished mammoth tooth plaquet. Photo: A. Dabasi

mennyiségű egyéb, elsősorban mezozoós mészkő mellett a kavics (kova és kvarcit) aránya Vértesnél 60\% körüli. A kész eszközökről azonban nem mindig lehet eldönteni, hogy kavicsból vagy tömb-nyersanyagból készült-e. Az eszközkészítő munkafolyamat első fázisaként a kavicsot „meghámozzák”, eltávolítják a kérget. Ez esetenként kiterjedhetett a teljes felületre is. Ha nincs kéreg, kiindulás lehet tömbkova vagy kavics egyaránt. A kavicsról (Kiesel) a monográfiában inkább csak negatívumok szerepelnek: nem alpi eredetû és nem a Duna hordalékából gyưjtötték (Végh-Viczián 1964:129-131).

Úgy vélem, a tatai eszközkészlet nyersanyagbázisa túlnyomóan kavics volt. Még a mezozoós mészkövekből sem az éles szélü, friss, hanem a kopott felületû, görgetett töredékeket hasznosították.

A Tatán és Vértesszőlősön használt, vélhetően azonos források helyét a Vértesszőlős-monográfia sem rögzíti pontosan. A felhasznált nyersanyag begyüjtésének, így a tatai közösség mozgáskörzetének határai Markó András terepbejárásai eredményeként fognak kirajzolódni.

A feldolgozás végére a kova és kvarcit aránya a Vértes adataihoz képest (92\% kova, 7\% kvarcit - Vértes 1964:138) jelentősen módosulni fog, a kvarcit javára. A tipikus eszközök többnyire kovából készültek, a finom szövetú, homogén radiolarit aprólékos, gondos megmunkálást tesz lehetővé. A kvarcit aránya elsősorban a nem-standard eszközök kategóriájában 
jelentős, szemcsés anyaga esetenként a megmunkálás felismerését is nehezíti.

\section{Környezeti adaptáció, életmód}

Az élő környezet mindkét összetevője, a teljes vegetáció- és faunaspektrum döntő jelentőségű a zsákmányoló életmódot folytató közösségek számára. A dögevésről az aktív vadászatra való áttérést évtizedekig a középső paleolitikummal kötötték össze. A múlt század végére azonban az aktív vadászat újabb alsó paleolitikumi bizonyítékát tárták fel a schöningeni lignitbányában (Thieme 1997). 1995-ben a 300 000-400 000 éves lelőhelyen 20 ló maradványaival együtt fa lándzsákat találtak. Bár az aktív vadászat és a specializáció így már az alsó paleolitikumban is bizonyított, a nagyvadvadászat ezen belül is a nagytestű csordaállatokra való specializáció elterjedését az Eem interglaciálistól tartja általánosnak S. Gaudzinski (2000:396). A két-három fajra specializált vadászat már az OIS 7 fázisban feltûnik, de az Eemben (OIS 5) lesz általános. Az OIS 6-tól hasznosítják a csontokat a lakó-építmények vázaként a barlang- és kőfülke-hiányos területeken.

A már hivatkozott szerzőpáros, Rolland és Dibble (1990: 489) az élő és élettelen környezet középső paleolitikus közösségekre gyakorolt hatását elsősorban a kőipar szempontjából vizsgálta. Arra jutottak, hogy a környék faunája és a topográfiai adottságok kevéssé befolyásolják a kőmegmunkáló (reduction) variációkat. Értelemszerűen sokkal inkább meghatározzák az élelem megszerzésének stratégiáját, a zsákmányoló és megtelepedési tevékenységet (killing and residence activity), a telepen végzett munkafolyamatokat, a feldolgozás menetét. A hideg sztyepp körülményei között az állati biomassza mennyisége növekszik, enyhébb, erdei vagy sztyepp körülmények között csökken, ugyanígy erre az időszakra a kevésbé intenzíven megmunkált eszközkészlet (less intensely reduced assemblages) a jellemző.

A technológia és az életmód kapcsolatáról újabb elméletet fogalmaz meg T. Baker és M. Kunz (2003). Szerintük a két kortárs paleoindián ipar (a bölényvadász Mesa és Folsom) eszközkészlete, eszközelőállító technikája, a technika hatékonysága, a ráfordított idő és energia közötti különbséget a nyersanyagforrásoktól való távolság határozza meg, és nem a funkció vagy a kulturális hagyomány.

M.-H. Moncel (2003b:70) a vegetációt a nyersanyag-beszerzés lehetőségei szempontjából is értékeli. A taubachi lelőhelyek gyakran kapcsolódnak meleg vizű forrásokhoz és az Eem erdős környezetének gazdag vegetációjához. Ugyanakkor néhány leletegyüttes környezeti mintázata azt mutatja, hogy ezek a mikrolitikus iparok nem mindig kapcsolódnak a mérsékelt égövi lombhullató, széles levelű erdei környezethez, ami elfedi a felszíni kibúvásokat és nehezíti a nyersanyaghoz való hozzáférést.

Az interglaciális klímajavulás, a relatíve magas páratartalom az erdők kiterjedését, s Közép-Európa keleti részén a lelőhelyek számának megnövekedését eredményezte, így pl. a taubachi telepekét is. Az interglaciálisban zömmel nyílt színi mésztufa lelőhelyeket találunk, amelyek nyílt foltok voltak erdei környezetben. J. Svoboda (1999) a vadászati specializációt, az elejtési helyek (killing sites) és a telepek elkülönülését nemcsak a környezeti feltételekhez, a vidék morfológiájához való alkalmazkodás példájának tekinti, hanem a fejlett felső paleolitikumig meg nem ismétlődő, fontos viselkedési mintázatnak tartja.

N. Rolland (1990) nagyszabású szintézisben foglalkozik Nyugat-Eurázsia középső paleolitikumával. Általánosságban megállapítja, hogy az élelemszerzésben a dögevés jelentőségének folyamatos csökkenése mellett az aktív vadászat különböző intenzitású gyakorlat volt. Vadásztak hajtásban a zsákmányra nézve válogatás nélkül, mesterséges vermekkel fiatal elefántra/mamutra és orrszarvúra (Weimar, Tata!), vagy szervezetten egyéni fegyverekkel (Torralba stb.).

A franciaországi középső paleolitikumra jellemző szerteágazó fejlődést (évolution buissonante) N. Rolland (1990) ökológiai változásokhoz köti. Az iparok elkülönítésének alapja a kaparók és a meghatározó típusok arányának változása, a magkőelőkészítés módja (a leütési felszín facettált vagy sima) stb. Mérsékelt nedves környezetben a fogazott eszközös, enyhe és nedves klímában a tipikus, hideg és nedves körülmények között a Ferrassie típusú, hideg és száraz klímacsúcsok idején a Quina típusú moustéri iparok élnek.

Rolland két, a középső paleolitikus lelőhelyek/lelet-anyagok értelmezésében gyökeresen eltérő modellt elemez, bár elhatárolódik a szélsőségektől. Elismeri, hogy egy-egy lelőhely besorolását számos tényező befolyásolhatja. F. Bordes modellje megmarad az általa legjobban ismert DNy-Franciaországban, ahol az alacsony sűrűségű, területileg körülhatárolt, félig vagy teljesen letelepedett közösségek telepei a jellemzőek. Ez az életvitel konzerválja az eszközkészletet és minimalizálja a csoportok közötti kapcsolatokat. L. R. Binford általánosabb érvényú modellje a félnomád vadász-gyújtögetô területhasználatot tartja jellemzőnek az őskőkorban. Elkülöníti a megkülönböztetett funkciójú munkahelyeket/ telepeket (a zsákmány elejtése, feldarabolás, gyưjtögetés, bányászás) a megfelelő célszerszámokkal és az állandóan lakott alaptáborokat (residential loci), ahol csak néhány tevékenységet folytatnak (Rolland 1990:362).

A két tetszetôs, fél évszázada kidolgozott modell a hazai lelőhelyekre, tágabban a mikroeszközös lelőhelycsoportra, még tágabban a közép-európai középső paleolitikumra elméletileg sem adaptálható. A Bordes-modell néhány elemének érvényessége valószínúbb, ami F. Bordes nagy gyakorlati tapasztalatából következik. Az inkább teoretikus Binfordmodellnek a terminológiája is kérdéses: a „nomád” kategória etimológiájából következő, szigorúan vett néprajzi jelentését Binford annyira átértelmezi, hogy már részben sem fedi azt a tartalmat, amire született.

A felső paleolitikumra vonatkozóan nagyobb a merítés, s vannak kísérletek, hogy a mindennapos életvitelhez szükséges vegyes típusspektrummal rendelkező táborokat és a közeli barlangok átmeneti/szezonális telepeit (aszimmetrikus eszközkészlet, nyílhegyek?) összekapcsoljuk. Ezek a feltételezések még további bizonyításra várnak. Kézenfekvőek a Mogyorósbánya-Öregkő barlangjai, Pilismarót-pilisi barlangok 
párosítások, miután a nyílt színi lelőhelyeken elókerültek a korábban különálló entitásnak tartott barlangi gravetti vagy pilisszántói kultúra eszközei. Így a barlang mint élettér elvesztette feltételezett kizárólagosságát (Dobosi 2005-2006:37).

Tata és a többi travertin lelőhely fallal határolt, oldalról zárt medence, melynek területe és nagysága adott. Ez Vértesszőlősön és Tatán is nagyobb, mint 50 négyzetméter. Az előkerült leletanyag mennyisége alapján egyáltalán nem nevezhető alacsony sûrüségûnek (low density), ami ellentmond a Bordes-modellnek.

A típusspektrum a telep általános funkciójára, mindennapos életvitelére jellemző. Specializációra semmi jel nem utal, leginkább Binford alaptáborának (base camp) felel meg. A lelőhelyek alacsony száma a közeljövőben aligha fogja lehetővé tenni, hogy egy alaptáborhoz speciális funkciójú munkahelyfüzért tudjunk kapcsolni. Esetenként a leletek csekély száma miatt még az adott lelőhely típusának meghatározása is erősen elméleti. Jó példa erre a gyakorta használt „átmeneti vadásztanya”. Az átmenetiség rendben van, hiszen alig néhány tárgy kerül elő, de mitől vadásztanya? A „vadász” szóba belefér az elejtési hely (killing site), a feldolgozó hely (butchering place). Vagy vadászok átmeneti pihenője lenne néhány elkallódott tárggyal?

Az Északkelet-Dunántúl sarkában a kiterjedt travertin vidék telepeinek életét meghatározták a terület földtani adottságai. Egy-egy szúkebb körzet medence-sorozataiból mindig választható volt egy éppen száraz, ahol megtelepedhettek néhány szezonra. A bejárható környék élő és élettelen természeti forrásainak kimerülése után hasonló körülményeket találtak pár tucat kilométerrel odébb. Vértesszőlős különösen szerencsés, hiszen a mai kőbánya területén fellelt 8 gyűjtőpont zöme az egyidejúleg ott letelepedett közösségek lakóhelye lehetett, két esetben viszont négyszer illetve ötször tértek vissza ugyanoda, ugyanabba a medencébe, több generációs távollét, méternyi mésztufa illetve lösz lerakódása után.

Tatán számos példa van a területhasználatra, az élő és élettelen környezet kínálta lehetőségek felismerésére. Az élettelen környezetből a nyersanyagforrások és a lakóhelyül szolgáló medencék a fontosak.

A két, sok tekintetben hasonló lelőhely (földrajzi közelség, mésztufa-medence, azonos nyersanyag-felhasználás, mikrolitikus ipar), Vértesszőlős és Tata élelmiszerforrásai között lényeges különbségek vannak a tatai népesség hátrányára. Növényi eredetú táplálékkínálata a klimatikus viszonyok romlása miatt jóval szúkösebb lehetett, mint Vértesszőlős legalsó kultúrrétegének idejében. A két lelőhelyről származó botanikai makrofosszíliák csak részben tükrözik az őskőkori település idejének vegetációját. Vértesszőlős alsó két, mésziszapba ágyazódott településszintje részben egyidős a levéllenyomatok képviselte dús vegetációval. Tatán a település a homokos lösz lerakódása idején volt aktív, ami hidegebb és szárazabb időszakot jelez. A fedő és fekü mésztufája a beágyazódott levelekkel, termésekkel melegebb-nedvesebb éghajlat idején keletkezett. A faszén és a pollen biztosan a kortárs flóra maradványa. A bükk és a tölgy makkja, a fenyőmag, talán néhány gomba vagy fümag ma is lehet emberi táplálék.
A tatai nagyemlős fauna jó példa a több ökológiai fülke találkozásában rejlő lehetőségek kiaknázására:

- a nedves, forrás-közeli környezetet képviselik a kisemlősök, a hal, egyes békafajok, a vízimadár inkább a Duna közelségét, mint nagyobb, tartósan megmaradó vízfelületet jelez;

- a Kisalföld keleti peremén juthattak hozzá a száraz, füves pusztán élő, testtömegükben meghatározó zsákmányállatokhoz: mamut, orrszarvú, bölény, ló, Megaloceros, s a korhatározó Asinus;

- a hegyvidéki lejtők vegyes, lombhullató-tûlevelű erdeiben él a gímszarvas, a vaddisznó;

- és jelen van a faunában az egyes életszakaszaiban barlanghoz kötött barlangi medve és hiéna.

Táplálék lehetett néhány nagyobb testű csigafaj is (Dobosi 1999).

Vadászzsákmányként egy 10-15 év közötti és minimum hat fiatalabb (1-2 hónapostól 2 évesig) mamutborjú maradványai kerültek elő az 1958-as ásatáson. A gyapjas orrszarvú is fiatal állat volt (Kretzoi 1964:117, 120). Tetemes, bár számszerüen nem kiugró húsmennyiség. A további hét faj töredéke a mamut egyedszámának. Így a mamutborjúra specializálódott vadászat igazolható. Az 1995-2001 közötti ásatás nagyemlős leletei sem mennyiségileg, sem minőségileg nem változtatják meg döntően a fauna képét, az ekkor előkerült mamutleletek zömmel am úgyis a fedő mésztufába belecementálódott, majd újonnan kivésett/kitördelt mamutcsontok üledékbe keveredett töredékei. Az bizonyos, hogy a kőeszközkészlet ilyen méretü állatok elejtésére vagy feldolgozására alkalmatlan.

N. Rolland és H. L. Dibble (1990: 493) szerint az eszközkészlet arculatát számos, egymással folyamatos kölcsönhatásban lévő tényezô befolyásolja. Elsősorban a klimatikus viszonyok (palaeoclimatic phases associated with different industry types), amelyek meghatározzák az életmódot, a település jellege, a kultúrréteg intenzitása.

Módosítja e hatást, hogy a lelőhely szezonális vagy tartós (téli), nyitott (open air) vagy zárt (enclosed) telep. Kőfülkékben és barlangokban nagyobb a variabilitás és intenzívebb a megmunkálás, mint a nyílt színi lelőhelyeken. Példa rá a charenti és a yabrudi iparok eszközkészítő folyamata. Fontos tényező a vadászott állatok életmódja, a nyersanyaglelőhelyektől, bányáktól való távolság. Nyilvánvaló, hogy az elejtési (killing) és feldolgozó (butchering) telepeken a célszerszámok fokozott használata a jellemző (Rolland 1990: Fig. 13.2). Az a megállapításuk is evidens, hogy a zsákmány feldolgozása az állatok méretétől és anatómiájától függ, az azonban meglepő megfigyelés, hogy a munkafolyamat nincs összefüggésben a szerszámkészlettel (Rolland 1990:390).

Az éghajlat meghatározó szerepére a közismert kalahári példát hozzák. A !kung szan közösségek száraz időszakban (paleolitikus párhuzam lehet a hideg-száraz stadiális) a víznyerő lyukak köré tömörülnek, csapadékosabb időszakban (interstadiálisban vagy enyhébb oszcilláció idején) a családok szétszóródnak (Rolland-Dibble 1990:489). Az egy éven belüli, évszakokhoz kötődő településváltás csak igen laza párhuzamba hozható a települési struktúra azon változásaival, 
amelyeket a geológiai léptékú éghajlat-ingadozásokhoz való alkalmazkodás eredményezett. Az erőforrások kimerülése csaknem valamennyi szempontot fölülírja.

A neandervölgyiek létfenntartásához kapcsolódó viselkedési mintázatokat vizsgálta elsősorban szúkebb szakterülete szempontjai szerint M. Patou-Mathis (2000). A telepek helyének kiválasztását számos szempont befolyásolja: a víz közelsége, a tüzifa, a zsákmány és a nyersanyag elérhetősége, a változatos élővilág, a védelem és a védhetőség stb. Ugyanakkor elsősorban a barlangokban nehézséget okoz a települési szintek és típusok elkülönítése, a települések időtartamának meghatározása. Nyílt színi lelóhelyek nagy változatossága elsősorban az elkülönülő funkciókból adódik: alap/téli táborhely, átmeneti vagy szezonális telep, zsákmányolóhely, kő nyersanyag vagy festék kitermelőhelyek (Patou-Mathis 2000: 391). Az alaptáborok viszonylagos ritkasága a logisztikai mobilitást feltételező elméletet erősíti (Patou-Mathis 2000). A lakótéren belül megjelennek a különböző tevékenységek elkülönülő területei, s szerencsés esetben (lelőhelybőség) a közösség territóriumának hasznosítására is van bizonyíték: egy alaptábor közössége szezonálisan és igények szerint lakja be a területét. A többfunkciós alaptábor és az időszakos/szezonális telepek közötti munkamegosztás, a források kimerülése okozta népmozgás logisztikai szervezést igényel. A mozgás többirányú, sugaras vagy csillag mintázatú. Kelet-Európában ez a territóriumon belüli népmozgás egyelőre ismeretlen okból átlépte a területi határokat és nagy, jelentős népmozgásokat eredményezett az Eem végén és különösen a korai Würmben (Patou-Mathis 2000:392). A szerző némileg eltér a konvencionális időrendtől: nála az Eem interglaciális csak az OIS 5e, az OIS 5a-d már a Würmhöz tartozik mint korai glaciális (Patou-Mathis 2000:392, Fig. 4).

A taubachi népesség két települési módot részesített előnyben. A szakirodalom elsősorban a mésztufa medencére figyel, s a kultúra egyik attribútumának tartja. A fallal védett, zárt lakótér kellemes (interglaciális, melegvizes) környezetben a hajdani lakóknak és a kutatóknak egyaránt vonzó: a település és a feltárás térben és időben belátható. Ám a barlang, mint az őskőkori népesség megszokott, mondhatni „közönséges” lakóhelye éppúgy gyakori. Mindenek előtt Kůlna, mint etalon. Magyarországon Tatán kívül az összes eddigi taubachi lelőhely barlangi. Diósgyőr-Tapolca esetében esetleg a kettő kombinációja is szóba jöhet, ha bizonyítható, hogy a hévforrások múködtek már az Eemben is. Nem lehet kizárni a nyílt színi, nem-medencés telepek előkerülését sem (WrocławHallera). Ez utóbbiakat nehezebb megtalálni, a mésztufa medence és a barlang elég feltűnő képződmény, s kézenfekvő települési lehetőség volt és maradt.

\section{Kulturális besorolás, kapcsolatok}

Az alsó és a középső paleolitikumban Eurázsia-szerte elterjedt kiseszközös leletegyüttesek/iparok/kultúrák nevezéktana nem tisztázott. Elnevezik lelőhelyről (Taubach, Buda), leírják mint kiseszközös vagy mikrolitikus hagyományt. A legkevésbé szerencsés, ha egy kultúrát egy korszak általános elnevezéseként alkalmazva, összeférhetetlen kategóriákat kapcsolunk össze: pl. eurázsiai apróeszközös acheuli (Eurasian Microindustrial Acheuléen).
A tág idő- és területi határok között elterjedt mikroeszközös iparok (a hosszú életű, OIS 25-23 korú Kuldara Tádzsikisztánban, s az OIS 5 korú közép-európai Tata és Taubach lelőhelyek) teljes jogú, független entitások, amelyek időről-időre, bizonyos ökológiai környezetben elkülönülve jelennek meg. A kisméretű kavicsok előnyben részesítésének vagy kizárólagosságának oka általánosságban ökológiai/funkcionális alkalmazkodás vagy szociális / szimbolikus szükséglet (azaz tradíció) (ecological / functional adaptation, or social / symbolic needs [i.e. tradition]) (Burdukiewicz-Ronen 2003). Nagyvonalú megfogalmazás ez, minden belefér, tetszés szerint kitölthető konkrét tartalommal. Konvencionálisan azokat az iparokat soroljuk ide, amelyek átlagmérete $30 \mathrm{~mm}$ körüli. A régészeti feldolgozás szempontjai szabadon választhatók, ám a nagy szabadság megnehezíti az összehasonlítást.

A téma két szakértője szerint nincs olyan objektív meghatározás, ami egyértelmúvé tenné a „mikrolitikus iparok” kategóriát: „The subjective definition 'tools too small to be conveniently held and operated in the hand' is still the only definition" (Burdukiewicz-Ronen 2003: 235). Ami már önmagában eleve értelmezhetetlen, hacsak fel nem tételezzük már az anteneandertáliakról (alsó paleolitikus gyökerek!) az öszszetett eszközök készítését és használatát.

Igaz ugyan, hogy már az alsó paleolitikumból (lignitben fennmaradt lándzsák, Schöningen) összetett fegyvert, azaz fa nyélbe erősített kőhegyet rekonstruáltak (idézi Burdukiewicz-Ronen 2003).

Vértesszőlős esetében az összetett eszközök csaknem kizárólagos használatát kellene feltételezni, ami még későbbi korokban sem valószínű. Itt a 8890 db standard és nem-standard eszközből mindössze 300 (3,4\%!) volt 50 mm-nél nagyobb (Dobosi 1990:347). Tatán ennek semmilyen szabad szemmel is észlelhető nyoma nincs.

Tata kapcsolatainak vizsgálatát legalább három irányból közelíthetjük meg. Egyik irány a topográfia: a kisméretû kavicsokat feldolgozó középső paleolitikus iparok széles közép-európai sávban koncentrálódó lelőhelyei. A nyersanyagbeszerző stratégiának és az eszköz-előállító technológiának az erős alsó paleolitikus gyökerei szórványosan egész Európában fellelhetők. Hosszú (lappangó?), közel hasonló ütemú fejlődés után közel azonos időben és azonos fejlettségi szinten jelentkezik a középső paleolitikus ipar. A térben és időben szükségszerű eltávolodás az elődöktől és a kortársaktól az eszközmegmunkáló hagyományt megőrző, mégis változatos leletegyüttesek létrejöttét eredményezte.

Másik, nehezebb irány a terminológia. Az általános nehézségekre jó példa a bennünket közelról érintő szeletai probléma, ahol több a kérdés, mint a válasz. Nincs tudomásom arról, hogy valaki újabban tételesen sorba szedte volna a szeletai kultúra általánosan elfogadott tipológiai, technológiai és kronológiai attribútumait. Az utolsó, s ezidáig egyetlen ilyen kísérlet, az 1966. évi Szeleta-szimpózium résztvevői által 9 pontban összefoglalt meghatározásnak a megállapításai már túlhaladottak (Vértes 1968). A sok mindent megélt szeletai kultúra kronológiai és topográfiai kiterjesztése a Krím-félszigetig (Chabai 2003: Fig. 9) kétség kívül kényelmes, 
ám nehezen indokolható. Ugyancsak a szeletai iparról írja Kaminská és szerzőtársai (2000:46), hogy a két szeletai fácies a közöttük lévő nagy kronológiai távolság és a technológiaitipológiai különbözőségek alapján nem ugyanazt a kulturális tradíciót képviseli (... they do not represent the same cultural tradition). A kultúra korai szakaszában a Szeleta-barlang és a morva szeletai leletei között alighanem csak a bifacialitás közös.

Budapestről szemlélve az is meglepő, ha az acheuli terminus technicus-t nem kulturális, hanem kronológiai egységként alkalmazó(?) monográfiában Vértesszőlős is szerepel.

Harmadik irány a kronológia. A szakirodalomban egységes az álláspont, hogy a kultúrkör lelőhelyei OIS 5/Eem interglaciális korúak. Tata-Porhanyó-bánya és köre besorolása nem nélkülözi a változatosságot. Időrendi sorrendben a következőket találtam:

\section{1-1912}

A régészeti leletanyagot a rendelkezésre álló szűkös összehasonlító anyag ellenére már 1911-ben a helyére tették, ami több szempontból is kiemelkedő teljesítmény. Egyrészt a tatai régészeti lelóhely felfedezésekor Magyarországon még csak a Szeleta-, Balla-barlang és a Puskaporos-kőfülke ásatásai kezdődtek meg. Másrészt az ásató/feldolgozó Kormos Tivadar nem régész, hanem paleontológus volt, viszont - mint ahogy Vértes László emlegette - okos ember volt: ,....dolgozata máig is mintaszerú példája a sok szempontú, földtani szemléletú öskôkori kismonográfiának" (Vértes 1965:93).

A tatai eredményekről szóló előzetes beszámoló, né-hány kőzetminta és fénykép ismeretében Wüst Ewald kieli egyetemi tanár 1910. december 13-án levélben keresi meg Kormost azzal, hogy nagy hasonlóságokat lát Weimar-TaubachEhringsdorf és Tata között: „Was ich nach Ihren Arbeiten schon vermuthete, bestätigt sich durchaus, nämlich daß Ihr Tata eine sehr große Ähnlichkeit mit unserem Weimar-TaubachEhringsdorf besitzt. Lagerung, Profile, Gesteinsentwicklung, Artefakte, und zum Theile auch Fossilien sind ganz ähnlich" (Kormos 1912:62). A „taubachi” tehát egyike a számtalan szakmai újrafelfedezésnek, még ha a két lelőhely akkor nem is indokolta egy önálló kulturális egység körvonalazását.

A leletanyag összefoglaló értékelése nem egyértelmű. „A tatai paleolit-ipar jellege tehát az, hogy az ember fejletlen technikája még nem uralkodik az anyagon, s a véletlen befolyása alatt áll" (Kormos 1912:44). Ennek némileg ellentmond a következő megállapítás: „A jobbára gondos kidolgozással ellátott kaparók kicsinységük mellett is jellegzetesek és jól megokolttá teszik Obermaiernek azt az elóttem hangoztatott véleményét, hogy a tatai ipar fiatal korát alátámasztja az a néhány darab, amely már az aurignacienre vall." (Kormos 1912:45). A MNM őskőkori raktárban, a Pb/290-299-es dobozban az eredeti, a Földtani Intézetben rendszeresített kísérő cédulán „aurignacien paleolitok" megjegyzés áll Kormos kézírásával (?).

A „finommunkájú késői moustérien” az első megnevezés. A hazai paleolitkutatás kései indulásához képest igen korai a szerteágazó fejlődés (évolution buissonnante) felismerése. Kormos Tivadar idézi Kadić Ottokárt, aki a Szeleta ásatásainak ismertetésekor írja: „Az a kérdés, vajjon minden iparnak, mely a solutréeni idöszakból való, okvetlenül minden részletben meg kell egyeznie? Úgy hiszem, nem. Ilyesmiról csupán ott lehet szó, ahol prehistóriai telepek közel voltak egymáshoz, ahol az emberek folytonos érintkezésben voltak, ugyanazt az anyagot használták, és ahol a megmunkálási szokások (sic!) az összes szomszédos telepeknek közös tulajdonává váltak. Amint azonban embercsoportok vándorlás, vagy valamely más természeti úton elkülönültek ... hosszabb izolációk folytán a megmunkálás szokásai és az ipar jelleme is változott." (Kormos 1912:50).

Ugyancsak ebben az évben írta Hillebrand Jenő: „Adva lévén a tatai löszlelöhelyen és a Kiskevélyi-barlang alsó rétegeiben talált paleolitheknek a hasonlósága, önkéntelenül felvetödik az a kérdés, vajjon nem ugyanazon néptörzs kezemunkájáról tanuskodik-e mindkét lelöhely" (Hillebrand 1912, 160).

\section{2}

Tóth L. (Hellebrandt et al. 1976:13) hivatkozik Saád Andorra, aki a Diósgyőr-Tapolca-barlangban 1932-ben végzett ásatása során több, mint ezer megmunkált tárgyat talált. Felfigyelt a barlang alsó, barna rétegéből előkerült kvarcit kavics eszközökre, és feltételezte a moustéri jelenlétét.

\section{4}

Hillebrand J. a Mannus folyóiratban publikált egy dolgozatot Tatáról. A levélhegyre emlékeztető, kétoldali megmunkálású kaparók miatt protosolutréen-nek határozta meg (a dolgozatra csak Vértes hivatkozásában bukkantam - Vértes 1959:34).

\section{5}

Gaál I. hírt ad arról, hogy a Szelim-barlang legalsó, „E” tűzhelyes rétegéből néhány közönséges fehér kvarcitból pattintott jellegzetes kóeszközt emeltek ki. A faszenek alapján ez a réteg enyhe klímában rakódott le, s ez megerósíti a tatai leletek moustéri besorolását és ökológiai hátterét (Gaál 1935: 60).

Ez évben jelent meg Hillebrand J. összefoglaló múve Magyarország őskőkoráról. A tipológiai szemléletű szerző a tatai eszközöket kevéssé tipikusnak tartja. Az elsősorban külföldi szakemberek által késő moustériennek minősített leletanyag analógiáját a Kiskevélyi-barlang alsó kultúrrétegének leleteiben találja meg. Véleménye azonos az előző évivel: ebben az összefoglalásban is megjelenik a protosolutréen-solutréen vonal (Hillebrand 1935: 13)!

\section{8}

Tata és a Kiskevélyi-barlang leletei egy kavicsokat feldolgozó késő moustérien kultúrába tartoznak. Harmadik megnevezés. Koruk Würm I/II. (Vértes 1958: 38)

\section{9}

Tata és a Szeleta „kapcsolata” a legszorosabb. G. Freund az európai levélhegyekről írt monográfiájában a levél-hegyek eredetét a bifaciális megmunkálású, hegyes tatai kaparókra vezeti vissza. Hivatkozva rá, Vértes leírja ezt a mondatot:

„... es eigentlich nur eine Frage der Nomenklatur sei, ob Tata Moustérien oder Szeletien genannt wird" (Vértes 1959:35). Ez az extrém gondolat nehezen értelmezhető. 
1960

Tata előtörténetének lényeges fejezete az Alt-Thüringen 4. köteteként megjelent monográfia. A kötetet szerzóként egyedül jegyző Behm-Blancke szerteágazó és nagy munkát végzett.

Weimar és környéke lelőhelyeinek (Weimar, Ehringsdorf és Taubach) első igazán modern szemléletű feldolgozása alapozata meg a taubachi karrierjét. Az Ilm Riss-kori teraszára rakódott mésztufa lepel több pontján talált lelőhelyek közül a legidősebb Weimar (E. antiquus faunával).

Régészeti iparát a szerző maga a Weimar kultúra I. fázisának határozta meg. Taubach kultúrrétege a Helicigona banaticaval jelzett interglaciális csúcs alatt van, azaz Riss/Würm első fele (Behm-Blancke 1960: Abb. 29). Kultúrája a Weimar kultúra II. fázisa.

A kultúrkörre vonatkozó negyedik elnevezés javaslat: a Weimar kultúra III. fázisa, azaz Ehringsdorf 4. rétege a tűzhelyekkel és a bifaciális eszközök nagy számával. (Az új módszereknek köszönhetően az ehringsdorfi kronológia azóta jelentősen átrendeződött, legalább egy geokronológiai szakasszal idősebb lett.) És újra azt találjuk: „...an interglacial Moustérien prészeletien A,...consequently a predecessor ... finally of the Szeletien" (Behm-Blancke 1960: 222).

\section{4-1965}

A Quartär-ben megjelent K. Žebera dolgozata cseh lelőhelyekről, amelyben Riss/Saale korú kavicseszközöket közölt (Sedlec, Mlazice) és a leletegyütteskre a „Bohémien” nevet vezeti be. A „kultúra” karrierjéről nincsenek adataim, de ha hitelesek a lelőhelyek, esetleg a későbbi (Eem) kavicsiparok elődjei közé sorolhatók (Žebera 1964-1965).

\section{4-1970}

1964. szeptember 10-i dátummal fejezte be Vértes László azt a kéziratot, ami csak 1970-ben jelent meg (Vértes 1970). A tatai ipar értékelésében új gondolatokat, ötleteket a vértesszőlősi alsó paleolitikus leletanyag megismerése hozott. Vértest az a kérdés foglalkoztatta, hogy az azonos nyersanyag és kőmegmunkáló technika Vértesszőlősön és Tatán menynyiben jelenti a két ipar azonos eredetét, kimutatható-e a középső paleolitikumban egy alsó paleolitikumban gyökerező epi-chopper kör. Azokban az iparokban, ahol döntően kavicsnyersanyagot használnak, fossile directeur az ún. Spaltenschaber (A. Rust: Zitrus-Schaber, A. Blanc: a spiccio), a kavicsgerezden (fruchtscheiben-förmige Spaltstück) előállított kaparó. A közép-európai hasonló leletanyagok (Bilzingsleben, micropontiniano és microtayacien kör lelőhelyei) áttekintése után Vértes László javaslata: „Diese Funde kann man ... alle zu einem gemeinsamen grossen Kreis als mittelpaläolithische Abkömmlinge des pebble/chopper-Phylum zusammenfassen, den man auch Epichopper-Industrien nennen könnte" (Vértes 1970: 30).

\section{4, ötödik javaslat, a Tata-monográfia éve}

Minden morfometriai adatot a legaprólékosabb statisztikai számításokkal kiértékelve, Vértes L. arra a következtetésre jut, hogy „Tata betreffend haben wir festgestellt, daß es sich zu einem «pseudo-Szeletien» entwickelt und die
Moustérientechnologie sowohl in der Spalttechnik als auch in den Werkzeugtypen beibehalten hat" (Vértes 1964: 236-242).

\section{5}

Vértes a Kézikönyvben is tartózkodik a „kultúra” megnevezéstől. Megismétli a monográfia következtetését: „A tatai eszközkészlet összképében erősen standardizálódott és kiegyénült, bifaciális késői moustéri, amely már nem fejlődhetett tovább a Szeleta-kultúra irányában, hanem önmaga öltött 'pseudoszeletai' jelleget” (Vértes 1965: 109). Ezt a nem túl szerencsés megállapítást később többször idézeték.

A Kézikönyvben ismerteti a Lambrecht Kálmán-barlangot, a Bükk északi részén, Varbó határában északra nyíló kis üreget, amelyben 1952-ben dolgoztak. Az alsó vörös barlangi agyagban Celtis és enyhe éghajlatra valló fauna kíséretében 7 kvarcit és 1 üveges kvarcporfír szilánkot találtak. A R/W intergaciális végére keltezett leletanyagot, miután idősebb a hazai moustérinél (figyelem, a könyv megjelenése idején a „moustéri” még mindig a középső paleolitikum szinonímája volt!), annak ellenére, hogy egyidős az európai moustéri egy részével, alsó paleolitikus korúnak határozta meg (Vértes 1965: 104-105).

\section{6-1968}

K. Valoch az Eem korú travertin-ipart a Weimar környéki lelőhelyek és Behm-Blancke alapján tayaci I-II-nek (Taubach és Weimar), illetve a későbbi levélhegyes iparok interglaciális gyökerének (Ehringsdorf) határozza meg. A Kůlna-barlang 11. rétegét $\mathrm{H}$. de Lumley nyomán Baume-Bonne típusú tayacinak írja le (Valoch 1968: 356; 1988: 76).

\section{8}

Megjelenik Gáboriné-Csánk V. Érd-monográfiája. A szerző megemlíti, hogy Érd Tatával együtt pontinien jellegü, s a felhasított kavics alapformák megegyeznek Vértesszőlőssel. Különbségek a méretben és a débitage-ban vannak, ugyanis Tatán a facetáltsági index (IF) 25,3, ami az eszközök méretét tekintve különösen figyelemre méltó, és Érden hiányzik a bifacialitás.

Ha a két radiokarbon eredmény közül az 50000 éves dátumot fogadjuk el, akkor a kora a Brørup interstadiális egyezik Érddel, ha a tatai eszközöket tartalmazó lösz Würm I. korú, akkor Tata fiatalabb Érdnél (Gábori-Csánk 1968: 250). Elfogadja Vértes álláspontját, hogy Tata „est un forme isolée $d u$ Moustérien, immobilisée dans son évolution du Moustérien, et ajoutons de notre côté: du «Moustérien sur galets »" (GáboriCsánk 1968: 248).

\section{2}

A bojnicei várdomb klasszikus travertinkúpjának nyugati oldalán található Bojnice III Hradná priekopa lelőhelyet a moustéri kultúra kárpáti fáciesének (Karpatská fácia moustierske kultúry) nevezi J. Bárta (1972: 3. kép).

\section{3}

A szepességi travertin-lelőhelyek iparát a közép-európai elterjedésú moustéri kultúra kárpáti fácieseként (Carpathian facies of Mousterian culture) írja le J. Bárta (1973: 62). 
1976

Ebben az évben jelent meg Hellebrandt M. DiósgyőrTapolca-i leletmentésének beszámolója. A barlangfürdő bejáratánál nyitott két szelvényben előkerült mintegy 200 megmunkált tárgyat Tóth L. értékelte. Az I. szelvény 4. rétegéből pattintékokat és eszközöket jelez az ásató. Az I. táblán a szelvény összes eszközét közlik, amelyből a 3. és 7. számú kaparó tartozhat a taubachi kultúrához (Hellebrandt et al. 1976: I. tábla). A II. szelvény 4. és 5. rétegében 32 eszközt találtak (Hellebrandt et al. 1976: II-VII. tábla). Tóth L. az eszközöket a Lambrecht Kálmán-barlang párhuzama alapján a „mousterien szélesebb értelemben vett csoportjához" sorolja (Hellebrandt et al. 1976:33).

Ugyancsak 1976-ban jelent meg Gábori M. monográfiája az Alpok és Ural közötti terület középső őskőkoráról. A Kárpátmedence iparait ismertetve, Gábori M. a Tata-típusú iparnak (Moustérien sur galets) két lelőhelyét említi, a névadó Tatát és a Csákvári-sziklaüreget (Gábori 1976: Fig. 16). A korai Würmre datált lelőhely egyidős Érd és Subalyuk felső kultúrrétegével, míg Gánóc (Gánovce) és köre (Hranovnica, Vyšné Ružbachy, Beharovce) Eem korúak (Gábori 1976: Fig. 19). A délkeleteurópai charenti (Érd) és a Tata-típusú ipar (Moustérien de type Tata) közötti különbség legalább fácies értékű (Gábori 1976:77).

\section{1}

J. Bárta és L. Bánesz (1981:12) tovább finomítják az 1973-as elnevezési javaslatot: kárpáti fáciesû mikro-moustéri (Micromousterian of Carpathian facies).

\section{4}

D. M. Collins 1969-es dolgozatában tünik fel a taubachi mint a klasszikus szakócás iparok Eem-beli hiányát betöltő egyik kulturális fílum. Collins szerint az Eemben hiányoznak a gazdag szakócás leletegyüttesek, és új együttestípusok jelennek meg. "The other, from Taubach, Rabutz, and other sites, has denticulates and relatively fewer unretouched Levallois flakes. One possibility is that the Taubach type, which often has a few badly-made handaxes in it, is in fact the Acheulian of Eem times." (Collins 1969:277). Tetszetős megfogalmazás, ám azok a rosszul elkészített 3-4 cm-es Taubach-(vagy akár Tata-) „szakócák” igazán nem említhetôk ebben az összefüggésben.

Collinsnak a Taubachra vonatkozó ötletét K. Valoch bontotta ki és öntötte formába. Bevezette a taubachi terminus technicust és rámutatott az ipar alsó paleolitikus gyökereire is: Bilzingsleben, Vértesszőlős és Isernia. Legtipikusabb képviselője a Kůlna barlang 11. rétege.

Az eszközök aránya a leletegyüttesen belül 6\%. A hosszúság átlaga 3,09 cm, a szélességé $3,24 \mathrm{~cm}$, a vastagságé $1,03 \mathrm{~cm}$. Leggyakoribb a sima talon, az eszközök negyedén maradt kavicskéreg, facettált a leütés az eszközök 6\%-án. A magkövek $30 \%$-a kisebb, mint 30 mm. A nyersanyag 33\%-a kréta kori tűzkő, 34\%-a kvarc, a maradék vegyes (Valoch 1988:73-75). Ez a tizenegyedik (Collins) elnevezés és mindeddig tartósnak bizonyul.

\section{8}

K. Valoch elsősorban a technológiai jellemzőket és különbségeket hangsúlyozza, amikor nem kultúrának, hanem technokomplexnek határozza meg a Kůlna-barlang két középső paleolitikus, taubachi és micoqui eszközegyüttesét (Valoch 1988:205).

\section{9}

Mester Zs. a Suba-lyuk revíziójáról szóló publikációjában elfogadja, hogy Tata egy sajátos, helyi változata a moustérinek. Kapcsolata a délkelet-európai charentihez, a pontini iparokhoz és a szlovákiai travertin-lelőhelyekhez még nem tisztázódott megnyugtatóan (Mester 1989: 28-29).

\section{1}

Bánesz L. az északi Kárpátok különböző korú travertinlelőhelyeinek régészeti anyagát elemzi. Gánovce, HôrkaOndrej és Beharovce a Liptói körzetben, a közép-szlovákiai Bešeňov, a nyugat-szlovákiai Bojnice és a morva-országi Kůlna (11. réteg) anyagát összeveti a közép-német Eem korú lelőhelyekkel (Weimar és Taubach). A prioritás szabályainak megfelelően a gánovcei (Gánovcien) elnevezést javasolja (Bánesz, 1991: 58).

\section{3}

Gábori-Csánk V. érintőlegesen ismét foglalkozik Tatával. A „meleg” mikro- és a „hideg” makrofauna közötti ellent-mondást ő is hangsúlyozza. Átveszi Gábori M. terminológiáját: „Tata représente une civilisation indépendante, le «Moustérien de type Tata»" (Gábori-Csánk 1993:109).

\section{4}

Dobosi V. és Vörös I. a Kiskevélyi-barlang anyagát revíziózza. Az 1912 óta ismert őskőkori lelőhelyen Hillebrand J., Vértes L. és Sasvári S. ásatásain több őskőkori kultúra leletei kerültek elő: a pilisszántói, a jankovichi és a kavics-moustéri. A 4. rétegben, vörös-sötétbarna barlangi agyagban 21 eszközt, zömében kaparókat és meg-munkált szilánkokat találtak. A nyersanyag közelebbről nem azonosított másodlagos kavicselőfordulás. A fauna alapján a lelőhely a felső pleisztocén Utrechti faunahulláma Subalyuk faunaszakaszának korai fázisába tartozik: prewürm-Würm I, kortársai Érd, Szelim-barlang és Tata (Dobosi-Vörös 1994).

\section{8-2004}

A kultúrkör technológiájának legjobb ismerője M.-H. Moncel 1998-ban már felrajzolja azt a közép-európai mikrolitikus kört, ahova másokkal együtt Předmostí II és Tata tartozik (Moncel 1998). Későbbi munkáiban is kitart a „taubachi” mellett (Moncel 2001; 2003a; 2003b; 2003c; 2004). Kétségeit ugyan már 2001-ben megfogalmazza: „The term «Taubachian » does not seem to describe the best way all the microlithic assemblages, dated to the OIS 5 and OIS 4, in this part of Europe and cannot be employed to designate a single lithic entity. The Taubach assemblage is not the best example of a microlithic assemblage." (Moncel 2001: 76).

Az apróeszközös világ (microlithic world) kora a középső pleisztocén vége és a felső pleisztocén eleje: OIS 9-4. Közép-Európától a Közel-Keletig és Közép-Ázsiáig, mintegy 40 lelőhelyet képvisel (Moncel 2001: 76). Legjelentősebbek Európából Taubach, Weimar, Stuttgart-Bad Cannstadt, Burgtonna, Rabutz és Wrocław-Hallera. J. Svoboda (1994: Tab. 5) kiegészítésével tovább bővült a lelőhelyek köre: Csehországból Bečov (A-III-3, B-III-I), Sedlec és Ládvi; Morvaországból Předmostí, 
Červený kopec, Kůlna 11. rétege és Modřice. Szlovákiából a klasszikus Gánovce, Bojnice (130-80 000), Nové Mesto nad Váhom és Hôrka-Ondrej tartozik ide (Kaminská 2000).

Magyarországon Tata, kapcsolódik hozzá a Dunántúlon a Szelim-, a Kiskevélyi-barlang és a Bükkben néhány lelőhely (a legjelentősebb a Diósgyőr-Tapolca-barlang). Tágabb körben csatlakoznak hozzá más kavicsos középső paleolitikus iparok, mint a Quina-körbe tartozó délkelet-európai charenti (Érden a kavicsok/eszközök mérete jóval nagyobb), a Pontinien az Appennini-félszigeten. Moncel feltételez egy nagy regionális trendet a kortárs középső paleolitikus iparokon belül (Moncel 2004: 106). Távolabb a Krímben a Kiik-Koba mikromoustérije és a keleti mikromoustéri (közelebb a Kaukázushoz) sorolható még ebbe a középső paleolitikus körbe. Az előzmények: Vértesszőlős, Trzebnica, Bilzingsleben (Moncel 2003c: Fig. 1).

A mikrolitizálódási hajlam bizonyított, a trend kimutatható, de a lelőhelymentes sávot egyelöre túl szélesnek tartom ahhoz, hogy a közép-európai lelőhelyekkel összekapcsoljuk a Kaukázus előterét.

\section{4}

Ringer Á. új szelvényt nyitott a Diósgyőr-Tapolcai-barlang bejárata előtt 1988-ban. Régészeti leleteket nem talált, ám mód nyílott összegyưjteni és újraértékelni a lelőhelyre vonatkozó régészeti, geológiai, és természettudományos adatokat. M.-H. Moncel a leletanyag technológiai elemzését végezte el. A barlangban és a bejáratnál előkerült összesen 619 tárgy nyersanyagspektruma figyelemre méltó: obszidiánt és kvarcporfírt is felhasználtak (Ringer 2002; Ringer-Moncel 2004: 163).

A kultúra bükki lelőhelyei a Diósgyőr-Tapolca-barlangon kívül a Lambrecht Kálmán-barlang (8 db), a Szeletabarlangnak a Kadić-féle sztratigráfia szerinti alulról második rétegében talált szintén 8 darab megmunkált kő (RingerMester 2000: 267) és a Büdös-pest-barlang 3. rétegének csekély leletanyaga (Ringer 2002: 302).

\section{Kronológia}

Tata-Porhanyó-bánya abszolút kronológiai helyzete az idők során jelentősen módosult. A korai „rövid” dátumok miatt több publikáció is azt sugallta, hogy a tatai középső paleolitikus népesség a nagy túlélő, a felső paleolitikus időszakban is élt a mésztufa-medence elszigeteltségében. Bár a hosszú túlélésre újabban Kelet-Európából vannak adataink (romániai barlangok fiatal dátumai: Cârciumaru-Pleşa 2004; Krím és Észak-Kaukázus: Chabai 2003). Tata esetében ezt a feltételezést nem indokolja semmi: egy lelőhely, egy települési szint megbízható kronológiai háttérrel.

A pleisztocén a taubachi kultúra időtartamát is magába foglaló utolsó 140 ezer esztendejének tagolására számos lehetőség nyílik. Egyik szélsőséges példája W. Dansgaard dán és $H$. Oeschger svájci klimatológus munkásságának eredménye. A grönlandi jég fúrásmintáinak kiértékelése során ebben az időintervallumban 25 rövid, de globális eljegesedési ciklust mutattak ki 1470 éves periodikussággal. Ezt kiegészíti az észak-atlanti-óceáni üledék elemzése alapján kimutatott Heinrich-féle 6 inter esemény. Reménykedjünk, hogy nem lesz mindegyiknek külön neve.

A másik véglet az utolsó eljegesedésnek elsősorban a vegetáció-történetben alkalmazott nagyvonalú beosztása: pleniglaciális $\mathrm{A} \approx \mathrm{OIS} 4$, interpleniglaciális $\approx$ OIS 3 , pleniglaciális $\mathrm{B} \approx$ OIS 2 .

A szakemberek éghajlati eseményekre, régészeti kultúrákra, rétegtani, faunisztikai egységekre is szívesen alkalmaznak nehezen követhető helyi elnevezéseket, ami látványos szinoptikus táblázatok sorát eredményezi. Ezek tartalmi vagy formai érvényességének kiterjesztése vitatható. Egyrészt ezeket a táblázatokat a folyamatosan módosuló idókeretek rendre átrendezik. Legújabban pl. a Paudorf talaj OIS 5 korúnak bizonyult, holott évtizedekig a felső paleolitikum egyik meghatározó viszonyítási szintje volt. A hazai terminológiából végleg kikopott a Göttweig interstadiális, ahova Kretzoi Miklós sorolta Tatát 1964-ben (Kretzoi 1964:125). „«Göttweiger Verlehmungs-zone» is significantly older than has been suggested in former studies" (>350 000), Thiel et al. 2011:137).

\subsection{Tata kronológiájának alakulása időrendben}

1912

Kormos Tivadar a Tata-monográfiában: „...(A tatai) fauna a pleisztocén idöszak fiatalabb szakaszának valamelyik interglaciális periódusából való" (Kormos 1912: 4).

1959

Vértes a Szelim- és a Kiskevélyi-barlang moustéri leleteivel és a dunántúli Szeletiennel együtt a Würm 1/2 interstadiálisra datálja (Vértes 1959: 38).

\section{4}

Tata-monográfia: a lelőhely 33 ezer éves, illetve más mérés szerint 50 ezernél idősebb (de Vries-de Waard 1964: 35-36). A természettudományos eredmények összegzése a lelőhelyet az interglaciális klímaoptimum utánra helyezi, az abszolút kronológiai értéket az akkor elfogadott határok (!) között adták meg.

1965

A Kézikönyvben: >50 - 40 ezer, esetleg öregebb adat szerepel (Vértes 1965:109).

1976

Gábori M. szerint Érd felső kultúrrétegével egyidős, >38 100, 35300 (Gábori 1976: Fig. 18)

\section{2}

A tatai mésztufa radiometrikus (Th/U) mérésen alapuló első abszolút kronológiai dátuma 99400 (Schwarcz-Skoflek 1982).

\section{0}

A vértesszőlősi monográfia kronológiai fejezetében Pécsi M. hivatkozik J. K. Osmonddal közös munkájukra: Tata kora 70 000-100 000 év. Ugyanott Pécsi M. idézi Hennig et al. (1983) dolgozatát: Tata abszolút dátuma 98800 (Pécsi 1990: 36). 
V. V. Cherdintsev és I. V. Kazachevski Tatára vonatkozó adata: 95000 (Cherdintsev-Kazachevski 1990: 547).

1993

Gábori-Csánk V. a két lehetséges ${ }^{14} \mathrm{C}$ alternatívát elemzi:

- ha az 50,000 évet fogadjuk el, akkor Érddel egyidős, Brørup interstadiális.

- ha a telepet magába foglaló lösz Würm 1 korú, akkor Érd valamivel idősebb.

Utoljára tûnik fel az irodalomban elfogadható koradatnak a 33000 (Gábori-Csánk 1993: 109).

\section{4}

Elkészült az északkelet-dunántúli negyedidőszaki édesvízi mészkőszelvények magnetosztratigráfiai korrelációja (Lantos 2004: fig. 10):

- Süttő (esetleg késó pliocén);

- Dunaalmás és Les-hegy: 230 méternél magasabb, két milliónál idősebb alsó pleisztocén;

- Buda-Várhegy és Budakalász: 1,1-0,5 Ma intervallum, ami már a Brunhes-Matuyama határtól (0,78 Ma) középső pleisztocén;

- Vértesszőlős: Brunhes kron középső C1n szakasza $\approx 0,4$ Ma.

- Tata: Brunhes kron fiatalabb rész.

2006

OTKA zárójelentésükben, Lantos M. és Korpás L. szerint a mésztufa egységesen normál polaritású, a Brunhes paleomágneses időszak fiatalabb szakaszában keletkezett. Az adatok a korhatározási módszerek jelenlegi tưréshatárain belül Tata-Porhanyó-bányát az OIS 5e szakaszra, 90-100 ezer év közöttre datálják (OTKA 2006).

A biológiai mintákból (botanika, malakológia) többnyire csak az adott időszak ökológiai körülményeire, mintasorozatok esetén az éghajlatváltozások irányára, ütemére, időtartamára vonatkozó adatok nyerhetők. A mésztufában megőrződött növénylenyomatok és a löszből nyert pollenek alapján a botanikusok a Riss/Würm második felétől a Würm 1 végéig tartó időszakot mutattak ki a bányából (Járai-Komlódi et al. 1964:85). Medzihradszky Zs. szerint a lösz és a homok kevés számú pollenje helyi éghajlat ingadozásokat jelez (OTKA 2006).

Krolopp E. szerint a kultúrréteg lerakódásának idején az éghajlat száraz és mérsékelten meleg volt, erdei faj nincs a csigafaunában (Krolopp 1964: 102). Újabb malakológiai vizsgálatok eredményeként a lelőhelyet a Trichina hispida-Bithynia leachi biozónán belül a Clausilia pumila szubzónába sorolják (Horváth-Sipos 1999: 16).

A makro- és mikrogerinces fauna feldolgozása során Kretzoi M. hasonló eredményre jutott. A település idején a mainál szárazabb és hưvösebb időjárás uralkodott, $19{ }^{\circ} \mathrm{C}$ júliusi átlaghőmérséklet volt a jellemző. A moustéri iparral együtt a lelőhelyet a Göttweig intervallumba (Würm 1/2) sorolta (Kretzoi 1964: 124).
Jánossy D. csak érintőlegesen foglalkozik Tatával. Subalyuknál valamivel idősebb, s a Lagurus és az Asinus hydruntinus alapján a R/W interstadiálisra, a Süttő-Varbó faunafázisra keltezi. Korrigál néhány meghatározást: barlangi medvét barna medvére és a hófajdot nyírfajdra (Jánossy 1979: 135).

A felső pleisztocén mikrogerinces fauna összetételének változása jól jelzi az éghajlati ingadozásokat az Eem interglaciálison belül. Az interglaciális melegcsúcsot (5e klimatozóna) enyhe lehúlés követi. 104 és 96 ezer év között az újbóli felmelegedés (5c klimatozóna) hatására visszatér a Microtus arvalis (mezei pocok) dominanciája, a Lagurus (pocoklemming) aránya állandósul, a Myodes (erdei pocok) gyakorisága növekszik, az Arvicola-é (vízipocok) viszont csökken. Tata-Porhanyó-bánya abszolút kronológiai adatai és a pocokfauna időkerete jól illeszkednek egymáshoz (Kordos-Ringer 1991: 526).

Az egybehangzó hazai és külföldi adatok alapján a tatai lelőhely időrendje reményeink szerint nyugvópontra jutott.

Tata-Porhanyó-bánya régészeti leleteinek feldolgozásában és a lelőhely értékelésében eddig jutottam. A munkát folytatjuk, a személyi és a dologi lehetőségek függvényében készül a monográfia.

\section{Felhasznált irodalom}

Baker, T., Kunz, M. 2003. Contrasting the Lithic Technologies of Mesa and Folsom. http://www.ele.net/ mesa_folsom/mesa_fol.htm

Bánesz, L. 1991. Die Entwicklung der Travertine in den Nordkarpaten im Lichte archäologischer Funde. Quartär 41/42: 45-62.

Bárta, J. 1972. Pravek Bojnic:.od staršej doby kamennej po dobu Slovansku. Obzor, Bratislava.

Bárta, J. 1973. Gánovce - the Hrádok Travertine heap. In: Guide to Excursion, 6th International Congress of Speleology. OlomucLiptovský Mikuláš, 57-63.

Bárta, J., Bánesz, L. 1981. The Palaeolithic and Mesolithic. In: Kolníková, E. (red.), Archaeological research in Slovakia. Papers presented at the Xth International Congress of Prehistoric and Protohostoric Sciences, Mexico 19-24 October 1981. Nitra: Institute of Archaeology of the Slovak Academy of Sciences, 11-29.

Behm-Blancke, G. 1960. Altsteinszeitliche Rastplätze im Travertingebiet von Taubach, Weimar, Ehringsdorf. Alt-Thüringen Band 4 (1959/60), Weimar: Hermann Böhlaus Nachfolger.

Burdukiewicz, J. M., Ronen, A. 2003. Research problems of the Lower and Middle Palaeolithic small tool assemblages. In: Burdukiewicz, J. M., Ronen, A. (eds), Lower Palaeolithic Small Tools in Europe and the Levant. BAR International Series 1115, Oxford: Archaeopress, 235-238.

Cârciumaru, M., Pleşa, M. 2004. Le paléolithique moyen tardif en Roumanie. In: Fülöp, É., Cseh, J. (eds), Die aktuellen Fragen des Mittelpaläolithikums in Mitteleuropa - Topical issues of the research of Middle Palaeolithic period in Central Europe. Tudományos Füzetek 12, Tata: Komárom-Esztergom County Museum Directorate, 221-232.

Chabai, V. 2003. The chronological and industrial variability of the Middle to Upper Palaeolithic transition in eastern Europe. In: Zilhao, J.. d'Errico, F. (eds), The Chronology of the Aurignacian and of the Transitional Technocomplexes. Dating, Stratigraphies, 
Cultural Implications. Trabalhos de Arqueologia 33, Lisboa: Instituto Português de Arqueologia, 71-86.

Cherdintsev, V. V., Kazachevski,K. V. 1990. Absolute date of the travertine samples. In: Kretzoi, M., Dobosi, V. T. (eds), Vértesszôlôs: site, man and culture. Budapest: Akadémiai Kiadó, 547.

Collins, D. M. 1969. Culture, Traditions and Environment of Early Men. Current Anthropology 10(4): 267-316. https://doi. org/10.1086/201019

Dobosi, V. 1983. Data to the evaluation of the Middle Palaeolithic industry of Tata. Folia Archaeologica 34: 7-32.

Dobosi, V. T. 1990. Description of the archaeological material. In: Kretzoi, M., Dobosi, V. T. (eds), Vértesszólös: site, man and culture. Budapest: Akadémiai Kiadó, 311-538.

Dobosi V. 1999. Ember és környezete. Élő és élettelen környezeti erőforrások két paleolit lelőhelyen. Komárom-Esztergom Megyei Múzeumok Közleményei 6: 5-21.

Dobosi, V. T. 2003. Changing environment - unchanged culture at Vértesszőlős, Hungary. In: Burdukiewicz, J. M., Ronen, A. (eds.), Lower Palaeolithic Small Tools in Europe and the Levant. BAR International Series 1115, Oxford: Archaeopress, 101-111.

Dobosi, V. T. 2004. Pebble tools from Tata-Porhanyó. In: Fülöp, É., Cseh, J. (eds.), Die aktuellen Fragen des Mittelpaläolithikums in Mitteleuropa - Topical issues of the research of Middle Palaeolithic period in Central Europe. Tudományos Füzetek 12, Tata: KomáromEsztergom County Museum Directorate, 65-75.

Dobosi V. 2005-2006. Gravetti lelőhelyek Pilismarót környékén. Folia Archaeologica 52: 21-48.

Dobosi, V.,Vörös, I. 1994. Material and chronological revision of the Kiskevély cave. Folia Archaeologica 43: 9-50.

Eibl-Eibesfeldt, I. 1995. Agresszió és háború: hozzátartozik-e az emberhez? In: Burenhult, G. (szerk.), Az első emberek. Az ember származása és östörténete. Budapest: Officina Nova, 26-29.

Gaál I. 1935. A bánhidai Szelim-barlang ásatása. Természettudományi Közlöny 67(198-199): 49-63. https://doi.org/10.1016/ S0033-3506(35)80140-6

Gaudzinski, S. 2000. On the variability of Middle Palaeolithic Procurement Tactics: The case of Salzgitter-Lebenstedt, Northern Germany. International Journal of Osteoarchaeology 10: 396406. https://doi.org/10.1002/1099-1212(200009/10)10:5<396::AIDOA559>3.0.CO;2-Z

Gábori, M. 1976. Les civilisations du Paléolithique moyen entre les Alpes et l'Oural. Budapest: Akadémiai Kiadó.

Gábori-Csánk, V. 1968. La station du Paléolithique moyen d'ÉrdHongrie. Budapest: Akadémiai Kiadó.

Gábori-Csánk,V. 1993. Le Jankovichien. Une civilisation paléolithique en Hongrie. E.R.A.U.L. 53, Liège: Université de Liège.

Hellebrand M., Kordos L., Tóth L. 1976. A Diósgyőr-Tapolca-barlang ásatásának eredményei. Herman Ottó Múzeum Évkönyve 15: 7-36.

Henning, G. J., Grün, R., Brunnacker, K., Pécsi, M. 1983. Th-230/U-234sowie ESR-Alterbestimmungen einiger Travertine in Ungarn. Eiszeitalter und Gegenwart 33: 9-19.

Hillebrand J. 1912. A Kiskevélyi barlangban 1912. évben végzett ásatások eredményei. Barlangkutatás 1(4): 153-193.

Hillebrand J. 1935. Magyarország öskőkora - Die ältere Steinzeit Ungarns. Archaeologia Hungarica 17, Budapest: Magyar Történeti Múzeum.

Horváth K., Sipos L. 1999. A tatai Porhanyóbánya régészeti geológiai vizsgálata. Országos Tudományos Diákköri Dolgozat, KLTE Ásvány- és Földtani Tanszék, Debrecen, kézirat.

Járai-Komlódi, M., Skoflek, I., Stieber, J. 1964. Die strati-graphische Wertung der botanischen Beobachtungen. In: Vértes, L. (Hrsg.),
Tata, eine mittelpaläolithische Travertin-Siedlung in Ungarn. Archaeologia Hungarica 43, Budapest: Akadémiai Kiadó, 83-86.

Jánossy D. 1979. A magyarországi pleisztocén tagolása gerinces faunák alapján. Budapest: Akadémiai Kiadó.

Jelínek, A. J. 1976. Form, function, and style in lithic analysis. In: Cleland, C. E. (ed.), Cultural change and continuity: essays in honor of James Bennett Griffin. New York: Academic Press, 19-33.

Kaminská, L. 2000. Chronologische Stellung der Mousttier-Funde von Hôrka-Ondrej im Rahmen der Zipser Travertinfundstellen. In: Mester, Zs., Ringer, Á. (dir.), A la recherche de l'Homme préhistorique. E.R.A.U.L. 95, Liège: Université de Liège, 233-245.

Kaminská, L., Ford, D. C., Hajnalová, E., Hajnalová, M., Horáček, I., Kovanda, J. 2000. Hôrka-Ondrej: research of a middle palaeolithic travertine locality. Nitra: Archaeological Institute of the Slovak Academy.

Kasztovszky Zs., T. Biró K., Markó A., Dobosi V. 2009. Pattintott kőeszközök nyersanyagainak roncsolásmentes vizsgálata promptgamma aktivációs analízissel. Archeometriai Múhely 6(1): 31-38.

Kele, S., Korpás, L., Demény, A., Kovács-Pálffy, P., Bajnóczi, B., Medzihradszky, Zs. 2006. Paleoenvironmental evaluation of the Tata Travertine Complex (Hungary) based on stable isotopic and petrographic studies. Acta Geologica Hungarica 49(1): 1-31. https:// doi.org/10.1556/AGeol.49.2006.1.1

Kordos L., Ringer Á. 1991. A magyarországi felső-pleisztocén Arvicolidae-sztratigráfiájának klimato- és archeosztratigráfiai korrelációja. A Magyar Állami Földtani Intézet Évi Jelentése az 1989. évrôl: 523-534.

Kormos T. 1912. A tatai őskori telep. A Magyar Királyi Földtani Intézet Évkönyve 20(1): 1-66.

Korpás, L. 2003. Basic pattern of Quaternary travertine: a review with special regard to the Hungarian deposits. Acta Geologica Hungarica 46(2): 131-138. https://doi.org/10.1556/AGeol.46.2003.2.2

Kretzoi, M. 1964. Die Wirbeltierfauna des Travertin-Komplexes von Tata. In: Vértes, L. (Hrsg.), Tata, eine mittelpaläolithische TravertinSiedlung in Ungarn. Archaeologia Hungarica 43, Budapest: Akadémiai Kiadó, 105-124.

Kretzoi, M., Dobosi, V. T. 1990.Vértesszőlôs: site, man and culture. Budapest: Akadémiai Kiadó.

Krolopp, E. 1964. Die Molluskenfauna. In: Vértes, L. (Hrsg.), Tata, eine mittelpaläolithische Travertin-Siedlung in Ungarn. Archaeologia Hungarica 43, Budapest: Akadémiai Kiadó, 87-102.

Lantos, M. 2004. Magnetostratigraphic correlation of Quaternary travertino sequences in NE Transdanubia. Földtani Közlöny 134(2): 227-236.

Markó, A., Kázmér, M. 2004. The use of nummulitic chert in the Middle Palaeolithic in Hungary. In: Fülöp, É., Cseh, J. (eds), Die aktuellen Fragen des Mittel-paläolithikums in Mitteleuropa - Topical issues of the research of Middle Palaeolithic period in Central Europe. Tudományos Füzetek 12, Tata: Komárom-Esztergom County Museum Directorate, 53-64.

Mester Zs. 1989. A Subalyuk-barlang középső paleolitikus iparainak újraértékelése. Folia Archaeologica 40: 11-35.

Moncel, M.-H. 1998. L'industrie lithique des niveaux eemiens de Předmostí II. Préhistoire Européenne 12: 11-48.

Moncel, M.-H. 2001. A technological approach of a microlithic assemblage: the site of Tata (Middle Palaeolithic, Hungary). Archaeologiai Értesítố 126: 75-98. https://doi.org/10.1556/ ArchErt.126.2001.1-2.3

Moncel, M.-H. 2003a. L'exploitation des petits galets dans des assemblages microlithiques du Paléolithique moyen d'Europe centrale. Külna et Predmosti II en Republique Tcheque, Tata 
en Hongrie. In: Peresani, M. (ed.), Discoid Lithic Technology: Advances and Implications. BAR International Series 1120, Oxford: Archaeopress, 225-239.

Moncel, M.-H. 2003b. Some Observation on Microlithic Assemblages in Central Europe during Lower and Middle Palaeolithic. Kůlna and Předmostí II (Czech Republic), Vértesszőlős and Tata (Hungary). In: Burdukiewicz, J. M., A. Ronen (eds), Lower Palaeolithic Small Tools in Europe and the Levant. BAR International Series 1115, Oxford: Archaeopress, 169-187.

Moncel M.-H. 2003c. Tata (Hongrie). Un assemblage microlithique du début du Pléistocène supérieur en Europe Centrale.L'Anthropologie 107: 117-151. https://doi.org/10.1016/S0003-5521(02)00005-5

Moncel, M.-H. 2004. Tata (Hungary), Kůlna (Czech Republic), Taubach and Weimar (Germany): a uniform Early Upper Pleistocene microlithic world (OIS 5)? In: Fülöp, É., Cseh. J. (eds), Die aktuellen Fragen des Mittelpaläolithikums in Mitteleuropa - Topical issues of the research of Middle Palaeolithic period in Central Europe. Tudományos Füzetek 12, Tata: Komárom-Esztergom County Museum Directorate, 91-134.

OTKA 2006. Az OTKA T038297 pályázat zárójelentése. Összeállította Kisné Cseh Julianna.

Patou-Mathis, M. 2000. Neanderthal subsistence beha-viours in Europe. International Journal of Osteoarchaeology 10: 379-395. https://doi.org/10.1002/1099-1212(200009/10)10:5<379::AIDOA558>3.0.CO;2-4

Pécsi, M. 1990. Geomorphological position and absolute age of the Vértesszőlős Lower Palaeolithic site. In: Kretzoi, M., Dobosi, V. T. (eds), Vértesszólös: site, man and culture. Budapest: Akadémiai Kiadó, 27-41.

Ringer Á. 2002. A Bükk hegység kőkora. In: Baráz Cs. (szerk.), A Bükki Nemzeti Park. Hegyek, erdôk, emberek. Eger: Bükki Nemzeti Park Igazgatóság, 295-314.

Ringer, Á., Mester, Zs. 2000. Résultats de la révision de la grotte Szeleta entreprise en 1999 et 2000. Anthropologie (Brno) 38(3): 261-270.

Ringer, Á., Moncel, M.-H. 2004. The Taubachian from Diósgyőr-Tapolca cave (Hungary). In: Fülöp, É., Cseh, J. (eds), Die aktuellen Fragen des Mittelpaläolithikums in Mitteleuropa - Topical issues of the research of Middle Palaeolithic period in Central Europe. Tudományos Füzetek 12, Tata: Komárom-Esztergom County Museum Directorate, 159-174.

Rolland, N. 1990. Middle Paleolithic socio-economic formations in Western Eurasia: an exploratory survey. In: Mellars, P. (ed.), The emergence of modern humans: an archaeological perspective. Edinburgh: Edinburgh University Press, 347-389.

Rolland, N., Dibble, H. L. 1990. A new synthesis of Middle Paleolithic variability. American Antiquity 55(3): 480-499. https://doi. org/10.2307/281279

Scheuer, Gy., Schweitzer, F. 1990. Travertine formation of the Gerecse Mountains. In: Kretzoi, M., Dobosi, V. T. (eds) Vértesszôlős: site, man and culture. Budapest: Akadémiai Kiadó, 43-62.

Schwarcz, H. P., Skoflek, I. 1982. New dates for the Tata, Hungary archaeological site. Nature 295: 590-591. https://doi. org/10.1038/295590a0

Svoboda, J. 1999. Environment and Middle Palaeolithic adaptations in eastern Central Europe. In: Roebroeks, W., Gamble, C. (eds), The Middle Palaeolithic occupation of Europe. Leiden: University of Leiden, 81-92.

Thieme, H. 1997: Lower Palaeolithic hunting spears from Germany. Nature 385: 807-810. https://doi.org/10.1038/385807a0

Thiel, Ch., Buylaert, J.-P., Murray, A. S., Terhorst, B., Tsukamoto, S.,
Frechen, M., Sprafke, T. 2011. Investigating the chronostratigraphy of prominent palaeosols in Lower Austria using post-IR IRSL dating. Eiszeitalter und Gegenwart 60: 137-152. https://doi. org/10.3285/eg.60.1.10

Valoch, K. 1968. Evolution of the Palaeolithic in Central and Eastern Europe. Current Anthropology 9(5): 351-368. https://doi. org/10.1086/200922

Valoch, K. 1988. Die Erforschung der Kůlna-Höhle 1961-1976. Anthropos Band 24, Brno: Moravské museum.

Végh, A., Viczián, I. 1964. Petrographische Untersuchungen an den Silexwerkzeugen. In: Vértes, L. (Hrsg.), Tata, eine mittelpaläolithische Travertin-Siedlung in Ungarn. Archaeologia Hungarica 43, Budapest: Akadémiai Kiadó, 129-131.

Vértes, L. 1959. Das Moustérien in Ungarn. Eiszeitalter und Gegenwart 10: 21-40.

Vértes, L. (Hrsg.) 1964. Tata, eine mittelpaläolithische TravertinSiedlung in Ungarn. Archaeologia Hungarica 43, Budapest: Akadémiai Kiadó.

Vértes L. 1965. Az ôskôkor és az átmeneti kókor emlékei Magyarországon. A Magyar Régészet Kézikönyve 1, Budapest: Akadémiai Kiadó.

Vértes, L. 1968. Szeleta-Symposium in Ungarn, 4-11 September 1966. Quartär 19: 381-390. https://doi.org/10.2140/pjm.1966.19.381

Vértes, L. 1970. „Zitrus” (Epi-chopper) Industrien in Ungarn. In: Frühe Menschheit und Umwelt. Fundamenta Reihe A Band 2, Köln: Böhlau Verlag, 28-33.

Vértes, L. 1990. Typology of the Vértesszőlős industry (a pebble-tool industry from the Lower Palaeolithic of Hungary). In: Kretzoi, M., Dobosi, V. T. (eds), Vértesszólös: site, man and culture. Budapest: Akadémiai Kiadó, 301-306.

de Vries, H., de Waard, H. 1964. Die Untersuchungen des C-14Laboratoriums zu Groningen. In: Vértes, L. (Hrsg.), Tata, eine mittelpaläolithische Travertin-Siedlung in Ungarn. Archaeologia Hungarica 43, Budapest: Akadémiai Kiadó, 35-36.

Žebera, K. 1964-1965. Das „Bohémien”, eine Geröllindustrie als Vorläufer des mitteleuropäischen Moustériens. Quartär 15/16: 47-60. 